\title{
THE MAGIC CONFLUENCE: AMERICAN ATTORNEYS, CHINA'S RISE, AND THE GLOBAL VALUE CHAIN
}

\author{
Justin W. Evans*
}

\section{INTRODUCTION}

It is now widely acknowledged that the unprecedented rise of China's economic engine is one of the most compelling events in history. Many in the United States have considered the implications for American businesses and the U.S. economy. It appears that, with all of its complexity and risk, China is and will continue to be a unique prospect for American businesses and entrepreneurs. The legal industry is no different; yet no literature to date has afforded a complete view of the matter.

This article aspires to provide American attorneys with a comprehensive blueprint on how to benefit from China's economic rebirth. Many factors including the timing and extent of China's rise, America's position as the world's incumbent economic leader, the fundamental importance of law to doing business in the modern world, and the nature of the legal profession in the United States - are now converging to create an almost magic confluence of circumstances. Never before have attorneys from the United States enjoyed such a surge of new opportunities and potential for innovation.

Globalization is here to stay. As the world's economic leader, the United States has acutely felt the consequences of the new economic order. Businesses of all types operate abroad and partner with foreign firms. At the same time, older industries within the United States are suffering at the hands of cheaper and sometimes more talented labor from other countries. American attorneys and law firms have begun adjusting. As one eloquent scholar notes, "[e]vidence of internationalization is ubiquitous in the legal services market. Greater economic interaction among national actors ... has stimulated growing interaction among nationally based lawyers and law firms." As with many

* Judicial Law Clerk to Justice Brent E. Dickson (Indiana Supreme Court); Adjunct Professor of Business (Indiana University Kelley School of Business - Indianapolis) and Adjunct Professor of Political Science (Indiana University - Indianapolis). J.D. (cum laude), 2007, Indiana University School of Law - Indianapolis; M.B.A., 2007, Indiana University Kelley School of Business - Indianapolis; B.A. (honors), 2003, The University of Texas at Austin. Several outstanding professionals (see infra note 202), all innovators and leaders in the phenomenon of the US-China legal practice, provided insights greatly beneficial to this article. A few individuals in particular, however, went well out of their way to provide their valuable guidance, and I would like to acknowledge their contributions here as well: Kalley Chen (Partner, King \& Wood, Beijing); Hon. Charlene Barshefsky (Wilmer Hale, Beijing); Dr. Lucas S. Chang (Partner, Morgan Lewis, Beijing); Paul C. Deemer (Partner, Vinson \& Elkins, Beijing, Shanghai); David Livdahl (Partner, Paul Hastings, Beijing); Manual E. Maisog (Partner, Hunton 
service-oriented industries, the international movement of American law firms has been largely motivated by a desire to follow and retain existing clients, as well as to expand the client base to include lucrative foreign interests. ${ }^{2}$ This article illustrates that China's rise can behoove all American attorneys, not merely those practicing in the largest law firms.

Because the law is fundamental to doing business in the modern world and additional complexities are created in doing business across borders, attorneys hold a unique position in global commerce. As one practitioner observed, "[l]awyers play an important role in the deals that bring the world's nation-states closer together. By educating themselves about their clients, the deals, and the places the deals affect, lawyers ideally help ensure a productive and smooth-operating global market." 3 American attorneys, as it will be shown, hold an especially great potential for exercising this role, and China is distinguished as the destination for their focus.

Part II of this article briefly reviews the economic transition underway in China and considers what this transition means for American businesses generally. Part III implicates academic business literature to show why American attorneys hold a unique position in the global value chain, and why this is unlikely to change anytime soon.

Employing the two preceding sections, Part IV reviews the specific legal services U.S. attorneys can provide with respect to China. Additionally, this section identifies and evaluates the employers that will increasingly demand American attorneys with expertise in Chinese legal services. Part V argues that American lawyers, by virtue of their legal backgrounds, are advantageously positioned to compete in non-legal business capacities relating to China. Part $\mathrm{V}$ also explores some unique applications of the position American lawyers have to further capitalize on China's rise.

Part VI advises U.S. attorneys and law students on how they can best position themselves to pursue a career focused on China. This section also suggests and advocates specific courses of action. Finally, Part VII briefly concludes the discussion.

\footnotetext{
\& Williams, Beijing); Matthew McConkey (Partner, Mayer Brown JSM, Beijing); Steven N. Robinson (Partner, Hogan \& Hartson, Beijing, Shanghai, Hong Kong); Lester Ross (Partner, Wilmer Hale, Beijing); Benedict Tai (Partner, Jones Day, Beijing); and Xiaohua (Sarah) Zhao (Partner, Akin Gump Strauss Hauer \& Feld, Beijing). Special thanks also to Elizabeth Cole (Partner, Orrick, Herrington \& Sutcliffee, Shanghai), for her leadership and guidance through the ABA, and to Dr. Philip T. Powell (Clinical Associate Professor of Business Economics \& Public Policy and Chairperson of the MBA Program, Indiana University Kelley School of Business - Indianapolis), for his services as advisor on the early drafts of this article. The author can be reached at juwevans@alumni.iu.edu.

1. Carole Silver, Winners and Losers in the Globalization of Legal Services: Situating the Market for Foreign Lawyers, 45 VA. J. INT'L L. 897, 897 (2005).

2. Id. at 914.

3. Cynthia Losure Baraban, Note, Inspiring Global Professionalism: Challenges and Opportunities for American Lawyers in China, 73 IND. L.J. 1247, 1271 (1998).
} 


\section{WHY CHINA?}

\section{A. A Brief Survey of China's Growth}

A brief statement regarding China's economy is merited, as it offers one metric to quantify the opportunities that country is now affording the world. The global gross domestic product ("GDP") grew in 2005 by a rate of $3.5 \% .^{4}$ The United States and China grew by $3.2 \%$ and $10.7 \%,{ }^{6}$ respectively. China is by far the world's fastest-growing major economy: between 2000 and 2006 , China's GDP ballooned from US \$1.2 trillion to $\$ 2.6$ trillion. ${ }^{7}$ Other indicia are correlated with this increase in GDP. China's exports have expanded exponentially, from $\$ 325.6$ billion in 2002 to $\$ 969.1$ billion in $2006{ }^{8}$ Similarly, China's foreign direct investment expanded from $\$ 49.3$ billion to $\$ 78.3$ billion between 2002 and $2006 .^{9}$

Even the once-dubious Chinese stock market now reflects the country's awesome progress. For example, a 2007 downturn in China's stock market reverberated throughout the world for the first time. ${ }^{10}$ And while there are differing opinions as to the attractiveness of China's stock market today, ${ }^{11}$ few seriously question its long-term viability. All other things being equal, there exists a dire opportunity cost for ignoring China: un-competitiveness on a global scale, which ultimately threatens total business failure.

\section{B. Implications of China's Economic Rise for American Businesses}

As with any other investment abroad, an American interest doing business in China, or with a Chinese firm elsewhere, assumes some degree of risk. Yet it is equally clear that China's business environment boasts some

4. The World Bank Group, World Data Profile, Apr. 2007, available at http://devdata.worldbank. org/external/CPProfile.asp?PTYPE=CP\&CCODE=WLD.

5. The World Bank Group, United States Data Profile, Apr. 2007, available at http://devdata.worldbank.org/external/CPProfile.asp?PTYPE=CP\&CCODE=USA.

6. The World Bank Group, China Data Profile, Apr. 2007, available at http://devdata.worldbank.org/external/CPProfile.asp?PTYPE=CP\&CCODE=CHN.

7. Id.

8. THE WORLD BANK, CHINA: KEY INDICATORS, http://siteresources.worldbank.org/INTEAPHALFYEARLYUPDATE/Resources/5501921194982737018/Indicators-EAP-Update-Nov2007.pdf.

9. Id.

10. Maria Bartiromo, China Syndrome: How Scary?, Bus. WK., Mar. 12, 2007, at 106.

11. Compare id. (citing Don Straszheim, vice-chairman of investment bank Roth Capital Partners, who commented, 'I'm a skeptic about many of the equities on the Shanghai and Shenzhen markets ... [Those] markets are still highly vulnerable, with enormous inherent risk to Western investors ... .") with Brian Bremner, Doing the Shanghai Shuffle, Bus. WK., Mar. 12,2007 , at 44 (indicating "[s]tock gyrations, however savage, have little impact on [China's overall growth] trends .... The real danger to investors isn't a stock market crash but a Chinese economy that grows so fast the government has to intervene and slam on the brakes."). 
exceptionally attractive attributes. As the U.S. Department of State has noted, "China's ongoing economic transformation has had a profound impact not only on China but on the world. [China's] market-oriented reforms . . . have unleashed individual initiative and entrepreneurship. The result has been the largest reduction of poverty and one of the fastest increases in income levels ever seen."12 China's accession to the World Trade Organization has encouraged and will continue to encourage market reforms, which in turn will create still greater potential for foreign businesses. While "serious concerns remain, particularly in the realm of intellectual property rights protection[,]"13 China has nevertheless "made significant progress implementing its WTO commitments ...."14

China has a compelling interest in continuing to open its economy to the world. ${ }^{15}$ Chinese law and policy, as the mechanisms through which the country's economic reforms are implemented, play a fundamental role in their economic expansion. Through its laws and policies, China continues incremental liberalization.

Two noteworthy scholars cite "at least five reasons why the need to become global has ... become a strategic imperative for virtually any mediumsized to large corporation." 16 These reasons include: the need to grow, the need to be efficient, the need to expand one's knowledge base, the fact that customers are global, and the fact that competitors are global. ${ }^{17}$ With respect to China in particular, two especially appealing factors motivate American firms to attempt market entry. First, U.S. firms operating in China can take advantage of the country's relatively inexpensive and skilled workforce. ${ }^{18}$ Second, U.S. firms with a presence in China can more efficiently sell their outputs (whether goods or services) to the growing middle class there. ${ }^{19}$ Each step of the way, lawyers ultimately save costs, avoid future complications, and facilitate entry and operations.

U.S. businesses are also taking note of the international shopping spree

12. U.S. Department of State, Background Note: China, (Oct. 2007), http://www.state.gov/r/pa/ei/bgn/18902.htm.

13. Id.

14. Id. Numerous instances abound of U.S. goods now circulating in China. As one example illustrates, "U.S. agricultural exports have increased dramatically, making China [the U.S.'s] fourth-largest agricultural export market ... . Over the same period (2001-2006), U.S. imports from China rose from $\$ 102$ billion to $\$ 287.8$ billion." Id.

15. Id. "Opening to the outside remains central to China's development. Foreigninvested enterprises produce about half of China's exports, and China continues to attract large investment inflows." Id.

16. Anil K. Gupta \& Vijay Govindarajan, Managing Global Expansion: A Conceptual Framework, 43 Bus. HoRIzons, Mar.-Apr. 2000, at 45, 45.

17. Id. at $45-46$.

46 ,

18. See, e.g., Peter Coy, Just How Cheap is Chinese Labor?, Bus.WK., Dec. 13, 2004, at http://www.businessweek.com/magazine/content/04_50/b3912051_mz011.htm?chan=search.

19. See, e.g., A Billion Three, But Not for Me, ECONOMIST, Mar. 20, 2004, at 6. 
underway by their Asian counterparts. Several journalists have noted, "Chinese companies, flush with cash and in command of the world's lowest-cost manufacturing plants, are doing some foreign investing of their own." ${ }^{20}$ This foreign investment is rational: "China has now recognized that to achieve sustainable growth, it needs to develop its relationship with the global economy beyond a simple export-driven model." ${ }^{21}$ This is significant for American businesses. Chinese firms will become competitors around the globe, and Chinese firms may invest in U.S. businesses. The degree to which American interests can effectively mold the emerging picture to suit their interests will be a function of several things - including, inter alia, the quality of their legal counsel.

Barring some unforeseen catastrophe, China's economy should continue to advance. There is some awareness within the legal profession of what this means for attorneys. One observer of the Wisconsin legal market remarked,

[a]s China [grows], more Wisconsin companies are looking at business ventures there. Those business activities mean opportunities for the law firms representing state manufacturers and entrepreneurs .... Business opportunities [for U.S. law firms] will continue to grow as China's middle class increases and the country develops as a nation of consumers. ${ }^{22}$

While such awareness is encouraging, the next section of this article aims to more fully develop the potential that U.S. lawyers enjoy with respect to China.

\section{AMERICAN ATTORNEYS IN THE GLOBAL VALUE CHAIN}

\section{A. Law as a Fundamental Link in the Chain: Competitiveness Generally}

\section{Overview: The Nature of Services and the Work of Attorneys}

At times, lawyers produce what might be called a good: a legal document, for example, physically printed on paper. But at their core, lawyers provide services: "bundles of benefits, some of which may be tangible and others intangible, and [which] may be accompanied by a facilitating good or goods."23

20. Dexter Roberts, et al., China Goes Shopping, Bus.WK., Dec. 20, 2004, at 32.

21. ACCENTURE, China SpREads ItS WINGS - ChINESE Companies Go Global 2 (2005) http://www.accenture.com/NR/rdonlyres/6A4C9C07-8C84-4287-9417203DF3E6A3D1/0/Chinaspreadsitswings.pdf.

22. Tony Anderson, China Practice: Advice to Wisconsin Law Firms Establishing Offices in China, WisC. L. J., Feb. 8, 2006, at 1.

23. JaCk R. Meredith \& SCOTT M. Shafer, Operations Management for MBAs 8 
The nature of the legal profession presents U.S. attorneys with some unique opportunities and challenges in China.

Service operations lay claim to several distinctive characteristics, including the participation of customers in the service process, simultaneous production and consumption of services, time-perishable capacity, the role of customers' location in the determination of site selection, labor intensiveness, intangibility, and the difficulty in measuring output. ${ }^{24}$ Certainly, these characterize the U.S. attorney. Customers, for example, are participants in the legal service process: a lawyer typically meets with his or her clients to become familiar with their needs before commencing work on their behalf.

Service providers, including those in legal services, must often account for the locations of both their current and desired customers in their site selection. This makes intuitive sense: the nature of a "service" and the need for the customer to be involved in the process often make physical proximity necessary. Although time and technological innovations, especially the Internet, may be reducing the importance of geography in some contexts, legal services are unlikely to succumb altogether to the trend. ${ }^{25}$ The importance of proximity holds especially true for U.S. attorneys interested in practice related to China. There are several reasons for this, including the vital importance of relationships in China, the complexity of the Chinese business environment, and the importance to American attorneys of understanding the context in which their advice will be implemented. Additionally, "[f]or services, the process is the product. The presence of the customer in the service process negates the closed-system perspective that is taken in manufacturing . . . . [C] ustomer impressions of service quality are based on the total service experience, not just on the explicit service that is performed."26

Within the service process matrix, lawyers are categorized with other professional service providers. ${ }^{27}$ That is, lawyers offer services that are highly labor intensive and that are characterized by a high degree of interaction with, and customization for, clients. This buoys the competitiveness of American attorneys in both domestic and transnational practice.

(1999).

24. See James A. Fitzsimmons \& Mona J. Fitzsimmons, Service Management 27-33 (2nd ed. 1998).

25. Outsourcing has made some incursions into the American legal profession. Krysten Crawford, Outsourcing the Lawyers, CNNMoney.com, Oct. 15, 2004, http://money.cnn.com/2004/10/14/news/economy/lawyer_outsourcing/?cnn=yes. But "[state] licensing rules make it highly unlikely that the most lucrative work that lawyers do ... will ever leave U.S. shores." Id.

26. FITZSIMMONS \& FITZSIMMONS, supra note 24, at 34-35.

27. The service matrix is a four-quadrant grid. One axis concerns the "degree of labor intensity" while the other provides the "degree of interaction and customization." Each axis then has a row/column of "high" and a row/column for "low." Professionals (including lawyers) fit in the "high, high" box, as noted above. Id. at 24 fig. 2.1 . 


\section{The Enviable Position of the Legal Services Industry}

As a whole, service providers face a variety of challenges, including relatively low overall entry barriers, minimal opportunities for economies of scale, erratic sales fluctuations, no advantage of size in dealing with buyers or suppliers, product substitution, customer loyalty, and exit barriers. ${ }^{28}$ These very dimensions, however, reveal why professional service providers have fared well compared to non-professional service providers in resisting outsourcing. Barriers to entry are a fine example. Many professional endeavors require extensive training that is usually costly and highly competitive. In the case of lawyers, this training includes the costs associated with law school and the difficulty of gaining the formal license to practice. The legal industry, then, like many professional service occupations, is largely insulated from competitors.

Another example of legal services breaking free from traditional challenges concerns product and service substitution. Virtually all U.S. states make it a crime ${ }^{29}$ to practice law ${ }^{30}$ without a law license. The net result is that by virtue of the rigors of professional regulation, lawyers enjoy a kind of monopoly in providing legal services. Only a formally licensed lawyer may practice law. For a person or organization in need of legal services, there is no reliable substitute for a licensed attorney. ${ }^{31}$

Lawyers appear to avoid most of the other challenges that are common to service organizations as well. Large firms can enjoy economies of scale, particularly in the application of knowledge. Larger practices, and even well established smaller ones, do not often encounter extreme sales fluctuations. Larger firms can leverage size in dealing with buyers and suppliers, offer highly refined expertise not available elsewhere and can boast the best individual lawyers for particular types of cases. Firms also have connections within the legal world to decision-makers and other specialists. Attorneys and firms can command exceptional customer loyalty, not only by virtue of distinguishable quality and expertise but also because legal representation often involves access to the confidential information of clients - information that clients normally want to share as infrequently as possible.

For any stable, developed society, the law remains a fundamental dimension of business. Consequently, those who supply legal services will remain an integral part of the commercial and social value chain in both the United States and China.

28. Id. at 51 .

29. See, e.g., IND. CODE §33-43-2-1 (2006).

30. "The definition of the practice of law is established by law and varies from one jurisdiction to another." MODEL RULES OF PROF'L CONDUCT R. $5.5 \mathrm{cmt}$. 2 (2007). Most define the practice of law broadly. See, e.g., D.C. CT. APP. R. 49(b)(2).

31. Individuals, even non-lawyers, are free to represent themselves in legal matters. This is known as "representing oneself pro se." However, the advantages of hiring professional legal representation remain substantial. 


\section{Competitive Strategies of the U.S. Legal Services Provider}

Three basic competitive strategies are available to service providers: overall cost leadership, differentiation, and focus. ${ }^{32}$ Irrespective of one's strategy, the same basic principles apply to attorneys as to other service industries in winning clients. ${ }^{33}$ To this end, legal service providers should expressly consider their resources with respect to market demand. One useful tool for doing so is the resource activity map. ${ }^{34}$

The implications of this for a legal service provider's internal affairs depend upon the nature of the business. Michael Porter's original work

developed the concept of a value chain as a way to improve the coordination among various functional groups. The value chain approach ... emphasized the organization as a system of interdependent activities that create value for the customer ... . Porter's value chain presented a new view of management, depicting the organization as a system of value-creating vertical processes rather than a collection of independent activities. $^{35}$

Hence, a large law firm may structure itself differently from a smaller firm, consulting firm, or corporation. Legal service providers should not attempt to exempt themselves from the basic notions applicable to businesses in this regard. Reorganization in a global legal market may be warranted; innovative organization in China may also prove indispensable.

\section{Other Miscellaneous Considerations - U.S. Lawyers on the International Scene}

"The value a company creates," Porter writes,

is measured by the amount that buyers are willing to pay for a product or service ... . To gain competitive advantage over its rivals, a company must either perform these activities at a lower cost or perform them in a way that leads to

32. FITZSIMMONS \& FITZSIMMONS, supra note 24, at 52-55.

33. These tactics include availability, convenience, dependability, personalization, price, quality, reputation, safety, and speed. Id. at 55-56.

34. See generally Colin G. Armistead \& Graham Clark, Resource Activity Mapping: The Value Chain in Service Operations, 13 SERviCE INDUSTRIES J. 4, 221 (1993) (providing a resource activity map that links an organization's costs and resources to the services it provides. Resource activity mapping can, inter alia, help a legal services provider better understand its potential in the Chinese-services marketplace).

35. MEREDITH \& ShAFER, supra note 23, at 14 (citing MiChAel E. PORTER, COMPETTTIVE ADVANTAGE 33-61 (1985)). 


$$
\text { differentiation and a premium price (more value). }{ }^{36}
$$

This characterization applies to legal service providers as much as to any other enterprise, and gives rise to the question of how U.S. law firms are competitive globally.

One academic attributes the international competitiveness of U.S. law firms to a variety of factors. ${ }^{37}$ Some of these are structural (e.g., America's role in the global economy and the dominance of U.S.-based financial institutions and capital markets). ${ }^{38}$ Other factors, however, result from the skill set developed by members of American firms. Examples of these factors include genuine expertise in U.S. law, experience with sophisticated transactions, relationships with financial service firms whose activities are fundamental to the international economy, and a unique brand of pragmatism. ${ }^{39}$ This last factor is a notion with significant implications both for managing an American legal services provider in the international context and for U.S. attorneys in China who pursue opportunities beyond those that are strictly law related. ${ }^{40}$

American attorneys and their employers should seek out competencies in these areas. While the entry of a firm into the international scene is complex and challenging, ${ }^{41}$ American firms must appreciate the domestic competitive advantages that accrue to firms boasting a worldwide presence. As human resource gurus will likely agree, the people with whom a company is staffed are crucial to the company's performance. The same is true for U.S. lawyers in the international context.

American lawyers - culturally and educationally equipped as we are to be business planners - are uniquely qualified to serve as middlemen in [cross-cultural business transactions]. . . . Without them, good deals frequently die; bad deals more often survive ...."While an international lawyer need not be, indeed cannot be, a universal legal expert, he should at least be able to build bridges to foreign counsel and integrate their

36. Michael E. Porter \& Victor E. Millar, How Information Gives You Competitive Advantage, HARv. Bus. Rev., July-Aug. 1985, at 149, 150.

37. Carole Silver, Globalization and the U.S. Market in Legal Services - Shifting Identities, 31 LAW \& POL'Y INT'L Bus. 1093, 1093 (2000).

38. Id. at 1095. It is worth noting that when China's role in the global economy rivals that of the United States, American attorneys with expertise in China will be all the more competitive. Hence, we should anticipate an environment long-term in which expertise in China will behoove those in the American legal profession.

39. Id.

40. See infra note 73 and accompanying text.

41. See generally Symposium, The Future of the Legal Profession: Transnational Law Practice, 44 CASE W. RES. L. REV. 737 (1994) (providing an outstanding discussion concerning what a law firm will confront when it contemplates a foreign branch). 
work with his." ${ }^{, 42}$

American attorneys are uniquely positioned to contribute to the global value chain. This position is magnified in the business context, as U.S. attorneys are trained to provide help in business planning, and not merely to give legal advice.

From a client's perspective, one of the chief values added by professional legal representation is the mitigation of risk. ${ }^{43}$ The knowledge, skill, and viewpoint that U.S. attorneys bring to international transactions serve to make their clients more competitive in foreign environments. This is true even when the client retains local counsel. ${ }^{44}$

A successful American corporation operating in China should evolve in three phases: entry, country development, and global integration. ${ }^{45}$ In each of these phases, U.S. attorneys can and should add value to corporate clients as they fight to compete in China. During the entry phase, for example, a corporation's goals are two-fold: "determine the right business model" (use China as a manufacturing base and/or sell in China) and "establish a presence" (choose a locality; select a partner, if any; learn the domestic operating environment; and begin to establish the brand). These goals suggest that the ideal China manager is entrepreneurial, creative, flexible, and has experience in developing countries. ${ }^{46}$ Plainly, American attorneys well versed in business planning fit this mold. In a place as complex as China, lawyers can assume an even more enhanced stature as business advisors. Attorneys can account for the legal repercussions of strategic choices and for the practical realities of the business environment itself. A similar rationale holds for the country development $^{47}$ and global integration ${ }^{48}$ phases.

\section{Initiative - The Key Link in the Chain}

Based upon the foregoing, American attorneys might be confident that

42. John P. Cogan, Jr., The International Lawyer as Conductor of the Global Symphony, in CAREERS IN INTERNATIONAL LAw 31, 43 (Mark W. Janis \& Salli A. Swartz eds., American Bar Association 2001) (citation omitted) (emphasis added).

43. See generally Donald R. Lessard, Risk and the Dynamics of Globalization, in THE Fưture of THE Multinational CoMPany 76 (Julian Birkinshaw, et al. eds., 2003) (discussing risk).

44. See infra Part III.B.

45. Kenneth Lieberthal \& Geoffrey Lieberthal, The Great Transition, in HARVARD Business Review on DoIng Business In ChInA 1, 17 (2004).

46. See id. at 17-18.

47. Here, a corporation's goals are to: expand the operation to several initiatives and several localities; coordinate lobbying and negotiation with the Chinese government across business units; and articulate an approach of "one face to China." Id. at 17-19. An "expansion of operations" always generates legal questions, particularly in China, where localities vary greatly in their legal, cultural, and economic idiosyncrasies.

48. During the third and final phase, a corporation has only one overarching goal: to establish full integration of its China operations into regional and global efforts. Id. at 18-19. 
their place in the global value chain is secure. This is a misguided inference. The foregoing shows merely that the potential for American lawyers in the global value chain is extraordinary (indeed, unrivaled). But their actual place will not be realized unless American lawyers take the initiative on a broad scale to seize these new opportunities. History has shown that regardless of the manner in which an economy is structured, demand has a curious way of being met. American attorneys are uniquely positioned to capitalize on China's rise, but they must take the initiative. ${ }^{49}$

\section{B. Why American Lawyers Will Remain Competitive Vis-à-vis Chinese Lawyers}

How can American lawyers hope to gain China-related work, let alone realize spectacular opportunities, when Chinese lawyers are also on the rise? China authority James McGregor advises U.S. companies to "[not] rely exclusively on the law in China. You will lose. Use laws and regulations to enhance political and business arguments in favor of your position."50 Yet a nagging question remains: why will American lawyers be required? U.S. counsel does, after all, cost more. As it turns out, China's own complexity creates opportunities for American lawyers vis-à-vis their Chinese counterparts, even in matters related to China.

\section{It's Not All Rosy - Challenges for American Attorneys}

U.S. attorneys cannot simply enter China's market and expect to be competitive. They must fight an uphill battle to establish their role in the global value chain. Three factors suggest the proportions of this struggle: the inherent advantages accruing to native firms; the intensity of competition in the Chinese legal services market; and crackdowns by the Chinese government against foreign legal service providers.

Considering the first of these factors, it comes as no surprise that Chinese law firms argue that they are better positioned to provide legal services in China. ${ }^{51}$ In support of this, Chinese attorneys advance several claims. First, they declare, the English language capabilities of Chinese law firms have improved over the last ten years. ${ }^{52}$ Though not implausible, there does not appear to be any concrete data to substantiate this claim. Even if this is accurate, it is hardly sufficient to conclude that outside firms are condemned to

49. See infra Part VI.

50. James MCGRegor, ONE BILUION CUSTOMERS: Lessons From the Front LiNes OF DOING BUSINESS IN CHINA 154 (2005).

51. See generally Glenda Korporaal, China's Homegrown Lawyers Step into the International Spotlight, THE AUSTRALIAN, May 5, 2006, at 29 (detailing how Chinese law prohibits foreign law firms from practicing domestic law in China and how Chinese law firms are more educated with regard to China's legal eccentricities).

52. Id. 
permanent impotence in the Chinese environment. Second, some claim, native firms understand Chinese culture and government better than foreigners do. ${ }^{53}$ While this is admittedly true as an initial matter, American attorneys are capable of "learning" Chinese culture and how the government functions to a highly competitive degree. ${ }^{54}$ Finally, it is noted, only Chinese lawyers may represent clients in Chinese courts. ${ }^{55}$ This, as it turns out, is not nearly so great an advantage as it appears at first blush. The Chinese legal system is distrusted such that even those disputes that are limited to Chinese parties seldom appear before a court. Instead, alternative dispute resolution is normally employed. ${ }^{56}$ Even those Chinese attorneys most enthusiastically advocating the foregoing strengths acknowledge their limitations. ${ }^{57}$

Irrespective of the inherent advantages enjoyed by Chinese attorneys, the competition in the Chinese legal services market is undeniably intense. ${ }^{58}$ "China is the most favored nation for new offices among [western] law firms . . . and the most difficult to crack. Competition is fierce among the [one hundred] foreign firms now operating in China ...."59 To complicate matters further, the competition is not supplied merely by other sophisticated, western interests: "Chinese law firms, with a lower cost structure, more associates and local contacts, are undercutting American and English firms on routine regulatory and compliance work required to establish small businesses . .." ${ }^{60}$ Virtually every Chinese industry that is no longer under government monopoly faces intense competition. While it appears that native Chinese firms are (at least for now) limited to "routine regulatory and compliance work," this work is nevertheless profitable. Moreover, much of the greatest potential in China lies with start-up companies. American lawyers would do well to compete not only

53. Id.

54. Perhaps the greatest advantage enjoyed by Chinese firms is the cultural distrust (or, at least, skepticism) of outsiders who have no relationships in China. It is crucial for Americans to be first-movers in establishing trust-based, working relationships with others in one's field. The forces of resistance can be countervailed by Americans with diligent persistence and immediate action. See infra Part VI.B.9.

55. Korporaal, supra note 51.

56. See infra Part IV.A.7.

57. These attorneys concede that many foreign law offices combine legal services with business consultation, creating a further competitive competency, and that, as a practical matter, foreign law firms are pushing the envelope in terms of what they do now. Moreover, the leading Chinese attorney interviewed for the Korporaal article "believes China will open the door for foreign lawyers to practice local law in China if the Government believes there is a market need." Korporaal, supra note 51.

58. Caroline Byrne, China Is the Most Favored Nation for Expanding Law Firms, INT'L HeRALD TRIB (Paris), May 17, 2006, at 16 (describing the intense competition in the Chinese legal marketplace).

59. Id. Indeed, "'China is a staggeringly big challenge for a law firm,' Christopher Stephens, the head of Orrick's team in the country, said .... 'You have to commit on real estate and people, a new tax regime, a new currency and a new banking regime without knowing with any certainty what return you are getting." Id.

60. Id. 
for large corporate clients, but also for the small businesses that will someday become global. ${ }^{61}$

A third force that makes the Chinese legal services market so challenging is the country's ubiquitous government. While China is plainly not a liberal democratic state, ${ }^{62}$ one distinguished scholar makes the compelling case that the government is becoming increasingly responsive to business lobbying. ${ }^{63}$ Nevertheless, foreign law firms in China are feeling protectionist resistance. For example, the Shanghai Bar Association implied it would push the Chinese Ministry of Justice to crack down on foreign law firms for conducting unauthorized activity. ${ }^{64}$ Resistance like this is not surprising; it is a phenomenon occurring every place in which globalization is making inroads, including the United States. American attorneys hoping to compete in China cannot forget this. Chinese legal service providers may not be motivated exclusively by their desire to remain competitive. In China, where a cultural respect for authority and order combine with a Sino-centric worldview, most Chinese take exception to what they regard as criminal behavior that other cultures might not. American attorneys will have to leverage the full force of their skills to optimize the competitiveness of their own operations, thereby denying native firms some clients, without offending local ethical mores.

\section{U.S. Lawyers Providing Services in or About China-Generally}

Notwithstanding these challenges, U.S. lawyers can and should bring to bear their own competitive competencies in the Chinese legal services market. The most distinctive of these tools is that American attorneys are best positioned to understand the big picture. On average, lawyers from the United States can more readily afford international training and experience than their Chinese competitors. As a result, American attorneys are better positioned to develop a cumulative understanding of the two legal systems and business environments. China expert John Chan remarked, "[w]hile some local lawyers [in China] are often cheaper [than international ones], if they have not spent extensive time in the West, they may not have the professional insight into or

61. See infra Part VI (discussing how to capture these clients).

62. See generally JUNE TEUfEl DREYER, ChINA's POLITICAL System (2008) (providing excellent information on Chinese government and politics). Businesspeople involved with China must have a sophisticated appreciation for the role that government and policy play in Chinese society.

63. See generally ScotT KENNEDY, THE BUSINESS OF LOBBYING IN CHINA (2005) (detailing lobbying in China). See also infra Part IV.A.8 (discussing the role of American attorneys in lobbying).

64. See China May Crack Down on Foreign Law Firms, China Dally, May 16, 2007, available at http://www.chinadaily.com.cn/china/2006-05/16/content_590787.htm. "[L]ike many Chinese laws, restrictions are vague. Foreign law firms are allowed to provide information about China's legal environment, but not to interpret the 'applicability of Chinese laws' ..." Id. See also infra Part IV.C.1 (discussing the restrictions China's law imposes on the ability of non-Chinese lawyers to fully practice in China). 
understanding of the foreign side to really act as an effective 'bridge.",65

Chinese lawyers are coming to embrace this reality: a refined macro-view of the world is an indispensable feature of today's competitive global attorney. A race is underway to determine who can train the fastest and the best, and attorneys from both $\mathrm{China}^{66}$ and the United States ${ }^{67}$ are in the running. Yet here, too, American lawyers generally have greater financial resources at their disposal, creating an advantage. There exists no reason why U.S. attorneys should fall behind their Chinese counterparts in developing global insight.

U.S. lawyers in China can remain competitive for several reasons in addition to their global vantage point. Oftentimes, for example, an American company interested in entering China will want to employ the insight and network of a local Chinese law firm. At the same time, however, the business may also want to retain its own lawyers, to give objective advice already known to be trustworthy and competent, and to manage the legal relationship between the company and its Chinese attorneys. Consequently, the demand for American attorneys operating in China should grow irrespective of the other advantages particular to them. Of course, U.S. counsel should help in the actual selection of foreign counsel. ${ }^{68}$

As Chinese businesses evolve, there may be demand for American lawyers on the payrolls of Chinese enterprises and law firms. Most of these will likely be consulting or managerial positions, ${ }^{69}$ but Chinese firms may also hire American attorneys as their legal counsel. This is especially true if the attorney is to work in the United States, where he or she is fully admitted to practice law. "'Chinese companies are now going west because they are so cash rich they are going to buy things .... They need a strong legal team to

65. John L. Chan, China Streetsmart 95 (2003). Even American lawyers who set up their own firms in China can leverage their expert global insight as against local competitors:

Ed Lehman, another excellent prominent China lawyer . . . is one of the few foreigners who work[s] for a Chinese law firm. In fact his firm today, Lehman, Lee \& $\mathrm{Xu}$, is registered as a local Chinese law firm. He commented that many of the local law firms operate more like a big shopping mall, with many of them working under one roof, but operating more independently.

Id.

66. One observer notes that "training from international organizations is in high demand from Chinese lawyers ...." The chief legal officer of a Chinese firm adds that "[i]nternational law firms . . . can help a lot with the training of in-house counsel, because as international lawyers, they have a legal education in foreign jurisdictions and they have practical experience." Clare Smith, The Challenge Facing China's Corporate Lawyers, Fin. TIMES, July 28,2005 , at 1 .

67. One authority notes that U.S. law firms often ignore foreign lawyers that earn LL.M. degrees in the U.S. Silver, supra note 1, at 915 . U.S. interests continue to favor American attorneys, though not exclusively.

68. See Salvador J. Juncadella, The Legal Profession in a Globalized World, 30 U. MIAMI INTER-AM. L. REv. 1, 6 (1998) (offering advice on how a multinational attorney should assist multinational clients in selecting a native lawyer in a foreign country).

69. See infra Parts IV.B., V.B.1., V.B.2. 
back them up when they are dealing with their counterparts in the [W]est.,"70

U.S. lawyers with experience in China may also discover that their legal backgrounds make them well suited to pursue non-legal opportunities there. Two of the most promising fields for such a career shift are consulting and entrepreneurship. While lawyers as consultants and lawyers as entrepreneurs are given a more robust analysis below, ${ }^{71}$ we should note here the inherent strength of these transitions.

With respect to consulting, one key 'aspect of U.S. lawyers' services is a particularly American pragmatism in approaching business and legal issues regardless of the applicable law. This quality ... is as important to the competitiveness of U.S. lawyers as it is elusive." naturals for becoming consultants.

With respect to entrepreneurship, a competent U.S. attorney already brings many skills to the table: an aptitude for using legal knowledge to foresee and elude many potential problems; a tendency to see the big picture; and a refined ability to weigh alternatives. ${ }^{73}$ Naturally, a lawyer must understand the entrepreneur's business before he or she can render sound legal advice. ${ }^{74}$ With this ability to understand business, together with venture skills and the entrepreneurial spirit, lawyers can themselves become successful entrepreneurs. The real-world potential for this appears to know few bounds. ${ }^{75}$ Lawyers desiring to become entrepreneurs must adopt the proper mindse ${ }^{76}$ and seek out experience as well as formal business training. Once these have been acquired, the American attorney will be uniquely positioned to create his or her own business in China.

70. Smith, supra note 66 .

71. See infra Parts V.B.2, V.B.4.

72. Silver, supra note 37 , at 1096-97 (citations omitted).

73. Jane Easter Bahls, Law Talent, ENTREPRENEUR MAG., Oct. 2004, available at http://www.entrepreneur.com/magazine/entrepreneur/2004/october/72712.html.

74. Id.

75. See generally Cliff Collins, The Engine of Growth: Lawyers Take a Lead in Helping Emerging Businesses to Grow, 59 OR. ST. B. BULL. 9, 12-13 (1998) (providing a broad overview of the role of attorneys in helping emerging businesses). See also infra Part V.B.4 (discussing the role of entrepreneurship and American attorneys in China).

76. See generally Marianne Moody Jennings, Lawyers for Entrepreneurs: Do They Exist?, 12 BUS. Forum, Spring 1987, at 4. One lament amongst businesses is their lawyers' outlook:

By the time they hit law practice, all new lawyers are seasoned in the art of telling clients what can't be done .... Lawyers are trained for compliance and not creativity. Lawyers often serve as a hindrance ... because they throw up obstacles intended for protection instead of functioning with the business client's commitment to success.

Id. Attorneys should be innovative problem-solvers rather than deal-stoppers. While legal training has evolved since the time Jennings enumerated these concerns, attomeys must nevertheless take care to emphasize innovation to keep themselves and their clients competitive in the global marketplace. Id. 


\section{A Natural Source of Competitiveness: Expertise in U.S. Law}

China has been criticized for moving slowly toward true liberalization in many of its industries, including the legal industry; ${ }^{77}$ however, American states have regulations in place to discourage foreigners from gaining a law license in the United States. ${ }^{78}$ Since the vast majority of people in the world who have credibility in American law are American lawyers, attorneys from the United States have another decisive advantage in the global value chain. On most occasions when U.S. law is implicated in a transaction between the United States and China, American attorneys will be involved on the U.S. side of the transaction. $^{79}$

Indeed, recent history shows that Chinese firms are increasingly in need of U.S. legal experts. "[T]he opportunities to provide legal services are not just a one-way street. China also is showing tremendous growth in the amount of money it is investing outside the country. 'The other opportunity we ultimately see is that Chinese companies will look to the U.S. to sell their products' . . " 80 American attorneys are increasingly finding very lucrative work defending Chinese firms in lawsuits brought in the United States. These actions typically involve accusations that the Chinese business in question has engaged in unfair trade practices or has otherwise violated U.S. trade and customs laws. ${ }^{81}$

\section{Many Transactions Require Independent Representation for Both Sides}

American businesses often enter into cooperation with a Chinese counterpart. Whether such arrangements are memorialized in a formal contract, both sides often desire to have their own representation throughout the negotiations and the ensuing relationship. The most common example of this is the joint venture. ${ }^{82}$

77. See infra Part IV.C.1.

78. See National Conference of Bar Examiners \& American Bar Association Section of Legal Education \& AdMISSION to tHe Bar, Comprehensive Guide to Bar ADMISSION REQUIREMENTS (Eric Moeser \& Margaret Fuller eds., 2007) available at http://www.ncbex.org/fileadmin/mediafiles/downloads/Comp_Guide/2007CompGuide.pdf (providing a synopsis of these regulations).

79. See supra Part III and infra Part IV.C.2 (for more on why the same need not necessarily hold true for American attorneys in China and Hong Kong).

80. Anderson, supra note 22.

81. See Murray Hiebert, When It Comes to Law, China Buys American, WALL ST. J., Feb. 17,2006 , at C1. Hiebert writes, "lawyers familiar with such cases estimate that they typically cost at least several hundred thousand dollars." Id. "The number of cases against Chinese exporters has grown to roughly half the total U.S. antidumping probes launched against foreign firms .... [O]fficials in Beijing say more Chinese corporations are looking for help from top U.S. lawyers." Id. One Chinese manager has stated that "hiring U.S. lawyers is now 'a must' even if they are expensive. "This is money worth spending, if you want to continue exporting to the U.S. market.'" Id.

82. See generally Yadong Luo, PARTNering WITH ChINeSe FiRMS: Lessons for 
There is a great deal of literature extolling the virtues of having a local partner in China. ${ }^{83}$ Under many circumstances, joint venture partners appear to be advantageous for American firms doing business in China. In deciding whether to take on a local partner, U.S. firms and businesses should consider a variety of strategic factors, including their own marketing competence, relationship building, market position, industrial experience, strategic orientation, and corporate image. ${ }^{84}$

American corporations should consult U.S. lawyers in the strategic evaluations of whether to enter China, whether to create a joint venture, and, if so, which Chinese firm to partner with. Additionally, U.S. attorneys can add a great deal of value during the actual creation of a joint venture. Because each side potentially has divergent interests, each should retain its own independent representation. Negotiations and the resulting legal documentation should optimize each partner's well being. Here, too, U.S. lawyers can add value for their clients in the complex Chinese context.

\section{5. "International" $\operatorname{Law}^{85}$}

For American attorneys interested more in international rules than the unique laws of China and the United States, but who nevertheless remain intrigued by China, a career in international law may be the right fit. In the abstract, a career in international law can encompass movement across frontiers, a procedural specialty, a substantive specialty, and practice as a generalist. ${ }^{86}$ In a more concrete sense, a major source of international law today arises from the World Trade Organization ("WTO"). "The WTO Agreement . . . is not self-executing," two experts explain.

\section{U.S. law reflects the U.S. interpretation and implementation of those international obligations and controls the conduct of a trade remedy proceeding in the United States. An exporting country that considers that the U.S. law or practice concerning such proceedings is not in conformity with the international standards may bring a challenge through the WTO dispute settlement procedures. A party that believes the conduct of a trade remedy proceeding is contrary to U.S. law has administrative and judicial appeal options in the United}

INTERNATIONAL MANAGERS (2000).

83. See, e.g., id. at 46.

84. Id. at $49-54$.

85. Strictly speaking, there is a difference between "international law" and "transnational law." Compare BLACK's LAW Dictionary 835 (8th ed. 2004) with id. at 1537. An attomey practicing "international law" works not with the unique laws of particular countries, but with agreements mutually subscribed to by multiple nations (e.g., WTO law). Id. at 835. In contrast, a "transnational lawyer" works with the unique laws of specific countries. Id. at 1537. However, for the sake of simplicity, this paper uses the terms "international" and "transnational" interchangeably.

86. Cogan, supra note 42 at $32-33$. 
States. ${ }^{87}$

A career litigating Sino-American disputes before the WTO, then, is one of many options that "international" American attorneys can pursue. ${ }^{88}$

\section{Concluding Thoughts - An Optimistic Outlook}

Part III has sought to show both that attorneys are central to the value chain of international transactions and that American attorneys can be competitive even as against the domestic Chinese legal industry. Although hurdles clearly exist, there is more reason to be optimistic than ever before. The opportunities now extending into both law-related functions and other professional endeavors appear to be boundless.

The following sections provide some practical insight into how one can actually go about building a career related to China.

\section{THE MECHANICS OF BUILdING A CHINA-RELATEd LEGAL CAREER}

\section{A. Substantive Legal Career Options}

\section{Overview: A Tremendous Diversity of Legal Functions}

The specific law-related services that American attorneys provide in relation to China are already substantial and continue to expand, seemingly by the day. ${ }^{89}$ At times, services related to China are stated generally. Consider for example, Baker \& Daniels, LLP, headquartered in Indianapolis: the firm (1) acts as "business and legal counsel to clients on the application of Chinese laws and regulations"; (2) represents clients in "mediation, arbitration, and litigation oversight"; (3) "coordinate[es] and advis[es] on enforcement of intellectual property rights"; and (4) advises "foreign investors on how to do business in China." Specific services can cover a wide range of disparate areas. Baker \& McKenzie, LLP, for example, uses its offices in China to advise in such fields as:

87. Peggy Clarke \& John D. Greenwald, An Overview of Trade Remedy Law, in TRADE REMEDIES FOR GLOBAL COMPANIES 1, 3 (Timothy C. Brightbill et al., eds., 2006).

88. See generally, e.g., Raj Bhala, INTERNATIONAL TRADE LAw: THEORY AND PRACTICE (2d ed. 2000).

89. See generally INTERNATIONAL LAWYER'S DESKBOOK (Lucinda A. Low et al., eds,. 2d ed. 2002) (providing a great overview of various international law practices). See generally Robert Haibin Hu, A Guide to Resources on Careers in Foreign and International Law, 93 LAW LIBR. J. 479 (2001) (providing an impressive collection of resources for China-related legal careers).

90. Baker \& Daniels LLP, China, http://www.bakerdaniels.com/ services/servicedetail.aspx?service $=470$ (last visited Mar. 11, 2008). 
[1] Banking and Finance; [2] Capital Markets; [3] China Trade and Investment; [4] Construction; [5] Corporate and Commercial; [6] Dispute Resolution; [7] Employment; [8] Insurance and other financial services; [9] Intellectual Property; [10] Major projects [and] Project Finance; [11] Mergers and Acquisitions; [12] Property; [13] Securities (both domestic and international); [14] Taxation; [15] Technology, Media and Telecommunications; [16] Venture Capital; [and] [17] WTO and Trade [matters.] ${ }^{91}$

Still other firms choose to specialize. Skadden, Arps, Slate, Meagher \& Flom LLP, for example, targets "[i]nnovative [m]ergers and [a]cquisitions," "[j]oint [v]entures and [d]irect [i]nvestment," "[p]rivate [e]quity", "[c]apital [m]arkets and [p]rivatizations," and energy project finance. ${ }^{92}$ And Vinson \& Elkins, LLP notes that their "Beijing office, staffed with U.S., English and PRC lawyers, maintains a practice primarily focused on developing, acquiring and financing infrastructure projects, including energy and telecommunications projects in China."

These examples indicate that some of the services currently offered by U.S. firms are specific to China (for example "China trade and investment"), while others are on par with services offered within the United States (for example, construction). The niche option is attractive, considering China's size and the complexity of its legal system. Other firms are pursuing the appealing strategy of breadth, in which a firm can serve as a one-stop shop for transactions in China. Whether a given firm should attempt the specialist approach or the generalist approach depends upon its resources, competencies, and overall strategy.

\section{The "Softer" Functions}

An American attorney providing legal services in China should fulfill two key functions that often go unappreciated in practice: bridging the cultural gap and promoting the rule of law. The first of these, "bridging the cultural gap," is motivated by a concern to provide the most effective representation possible. As one expert notes, the role of the transnational lawyer is "not simply to present the local legal structure, but also to provide a certain degree of guidance regarding the manner of compliance with local social and cultural aspects of the

91. Baker \& McKenzie, China, http://www.bakernet.com/BakerNet/ Locations/Asia+Pacific/Offices/China/default.htm (last visited Mar. 11, 2008).

92. Skadden, Arps, Slate, Meagher \& Flom LLP \& Affiliates, China, http://www.skadden.com/Index.cfm?contentID $=47 \&$ practiceID $=33 \&$ focusID $=1$ (last visited Mar. 11, 2008).

93. Vinson \& Elkins LLP, Beijing, http://www.vinsonelkins.com/offices/offices_detail_print.asp?H4OfficeID $=000320814305$ (last visited Mar. 11, 2008). 
foreign system." ${ }^{, 94}$ It is the human connection, and not merely skill, that adds value to business in China. ${ }^{95}$ The same is true for lawyers. Moreover, our ethics rules likely demand a sound grasp of Chinese culture for those whose practice is related to China. ${ }^{96}$

In addition to bridging the cultural gap, U.S. attorneys involved with China should seek to promote the rule of law there. The rule of law has not traditionally been a part of the Chinese culture; however, as China continues what appears to be a trend in favor of the rule of law, the transparency and stability of the business environment will be bolstered. China's embrace of the rule of law may be motivated more out of necessity in a globalized world than out of a truly internalized ethos. American attorneys would therefore serve their clients well, not to mention their own business interests, by proactively promoting the rule of law in China. The American Bar Association is a leading force in this area. ${ }^{97}$

\section{Advising on Chinese Law}

American attorneys can advise their clients on Chinese law. ${ }^{98}$ One expert recently noted that "[a]dvising on foreign law represents a new strategy for U.S. law firms." "[A]s rules of practice liberalized, firms most likely decided to add local law expertise to their offshore office offerings in order to generate revenue from these offices .... By going local - shifting foreign offices from a U.S.law focus to a local-law focus - U.S. firms have globalized their practices."

U.S. law firms have increasingly frequent occasions to advise their clients on substantive Chinese law. To meet this demand, U.S. law firms will need to recruit attorneys with some exposure to Chinese law. As with other areas of law, American attorneys can become competent in the laws of a foreign country through diligent self-study ${ }^{100}$ While some outstanding resources exist for selfstudy, ${ }^{101}$ perhaps the best preparation in this area is the LL.M. degree in

94. Roger J. Goebel, The Internationalization of Law and Legal Practice: Professional Qualification and Educational Requirements for Law Practice in a Foreign Country: Bridging the Cultural Gap, 63 Tul. L. Rev. 443, 453 (1989).

95. See infra Part VI.B.9 for more on the heightened importance of interpersonal relations to doing business with the Chinese.

96. See Goebel, supra note 94 , at 454.

97. See American Bar Association, Rule of Law Initiative, Asia, http://www.abanet.org/rol/asia/ (last visited Mar. 15, 2008) (detailing the ABA's Rule of Law initiative and its impact in Asian countries, including China).

98. In theory, American lawyers in China are somewhat restricted in the advice they can give to clients. In the Chinese context, it is difficult to tell where, in practice, the "practice of law" begins and ends. See infra Part IV.C.1.

99. Silver, supra note 1, at 922-23.

100. See MOdel RULES OF PROF'L CONDUCT R. 1.1 cmts. 1, 2, 4 \& 5 (2006).

101. See generally James M.ZIMMERMAN, China LAW DesKBoOK (2d ed. 2005) (providing what is likely the finest recent English-language, introductory-level guide to substantive Chinese law). 
Chinese Law. ${ }^{102}$ However, the LL.M. requires at least one year to complete; therefore, self-study may be a more attractive option to American attorneys, particularly for those already in practice.

\section{U.S. Customs and International Trade Law}

Another way for American attorneys to be involved with Chinese issues from the United States is to practice in U.S. customs and international trade law. ${ }^{103}$ This subfield has evolved considerably over time. ${ }^{104}$ Change is a great fount of opportunity for the legal profession, and this area is likely to remain dynamic in the future.

Trade remedies are the creation of federal law and are designed to provide protections to domestic business interests in the United States against foreign competitors. Trade remedies fall within three broad categories: antidumping, ${ }^{105}$ countervailing duties, ${ }^{106}$ and safeguards. ${ }^{107}$ There are four classes of safeguard actions, and two of them concern China specifically: general China safeguard actions and textile safeguards imposed on imports from China. ${ }^{108}$

Most trade remedy actions require an exhaustion of administrative remedies before resorting to the courts. Thus, an attorney may represent a client either before a regulatory body (such as the International Trade Commission) or before a court (the U.S. Court of International Trade or the U.S. Court of Appeals for the Federal Circuit).

In the public sector, a trade attorney might be involved with a variety of tasks, including trade agreements, trade-related legislation, dispute settlement, litigation, advice and advocacy for U.S. exporters and investors, and technical assistance for foreign countries. ${ }^{109}$ In the private sector, the range of jobs is at least as extensive, including employment as a country risk analyst, customs

102. See infra Part VI.B.5.

103. See Clarke \& Greenwald, supra note 87 , at $2-3$ for a concise synopsis of U.S. trade remedies.

104. See I.M. Destler, Changing the Rules: The Rise of Administrative Trade Remedies, in AMERICAN TRADE PoltTics 137-67 (4th ed. 2005) (providing a great synopsis of the development of U.S. trade remedy law).

105. "Antidumping cases involve claims that foreign producers/exporters in a particular country are selling their goods in the U.S. market at 'less than normal value' (sometimes referred to as 'less than fair value')." Clarke \& Greenwald, supra note 87, at 2.

106. These are claims that foreign businesses' government-subsidized imports are damaging or threaten to damage an American industry. Id.

107. Safeguards are other miscellaneous statutes designed to protect domestic industries against particular types of incursions and tactics from foreign competitors. Id. at 3.

108. Id. at 3. See also James M. Lyons, et al., Safeguards: An Overview of Global, China, Textile, and FTA Measures, in TRADE REMEDIES FOR GLOBAL COMPANIES, supra note 87, at 147, 155-57 (providing further information on these China-specific safeguards).

109. See Eleanor Roberts Lewis, The Practice of International Trade Law in the Public Sector, in CAREERS IN INTERNATIONAL LAW, supra note 42, at 101, 103-05. For an extensive list of opportunities in the federal government related to international trade law see id. at 109-11. 
broker, export credit manager, international trade analyst, international trade and investment consultant, and in banking. ${ }^{110}$

\section{Litigation}

American attorneys may be involved with litigation concerning Chinese entities within the United States. ${ }^{111}$ As trade and investment between the United States and China continues to grow, U.S. attorneys may increasingly find themselves involved with litigation in China. As noted before, foreign attorneys may not appear in a Chinese court on behalf of a client. ${ }^{112}$ A U.S. attorney may nevertheless be involved with the case, even if the attorney does not personally appear in court. Familiarizing oneself with how the Chinese legal process works (both in theory and practice) would behoove an American lawyer whose clients may find themselves before a Chinese court. ${ }^{113}$

\section{Business Negotiations}

American attorneys often assist their clients in domestic business deals and can provide the same service for clients negotiating with Chinese entities. The international dimension adds an exciting and challenging angle to the traditional function of an attorney. ${ }^{114}$ As with many other China-related jobs, conducting international negotiations with a Chinese firm places some unfamiliar obligations upon the American lawyer. ${ }^{115}$

Chinese culture presents some unique challenges for U.S. businesses and their counsel. Interpersonal relations, for example, take precedence over commercial transactions. ${ }^{116}$

A Chinese entity will not go into commercial cooperation with its counterpart until it has established a trust in that counterpart. Therefore, in China, large transactions between

110. JD PREFERRED 6.8-6.11 (1994).

111. See Hiebert, supra note 81 and accompanying text.

112. Korporaal, supra note 51. See also infra Part IV.C.1 (detailing the restrictions the Chinese government has placed on foreign attorneys with regard to the practice of law in China).

113. See generally Fang Shen, Comment, Are you Prepared for This Legal Maze? How to Serve Legal Documents, Obtain Evidence, and Enforce Judgments in China, 72 UMKCL. REv. 215 (2003) (discussing how Chinese litigation proceeds).

114. See generally Jay G. Foonberg, The Role of the Lawyer: A Checklist, in THE ABA GUIDE TO INTERNATIONAL BUSINESS NEGOTIATIONS 139, 139-145 (James R. Silkenat \& Jeffery M. Aresty eds., 2d ed. 2000) [hereinafter ABA GUIDE] (providing a useful checklist for the U.S. attorney entering international law).

115. See generally James R. Silkenat \& Jerffrey M. Aresty, Introduction, in ABA GUIDE, supra note 114, at 1, 1-3 (detailing the challenges faced by the U.S. attorney entering the international arena).

116. Zhang Jiachun, Zeng Shiji \& Li Li, International Business Negotiations in the People's Republic of China, in ABA GUIDE, supra note 114, at 399, 400-01. 
two companies usually come only after a friendship or at least some sort of acquaintance has been established between the leaders or personnel of related departments of the two companies. $^{117}$

U.S. attorneys cannot be satisfied with mere efforts to extract favorable terms from the Chinese side. Rather, American attorneys represent their clients in negotiations best when they invest themselves in fostering relationships between their clients and the Chinese personnel.

Negotiations can be complicated by the fact that Chinese attorneys are not held in the same social esteem as their counterparts in the United States. The Chinese historically associate lawyers with confrontation; thus, many Chinese firms even today will not have lawyers present during any business negotiations. ${ }^{118}$ Americans understand that attorneys have many nonconfrontational functions, including assistance in business negotiations, and Chinese business leaders are beginning to appreciate this distinction in the Western tradition. ${ }^{19}$ Hence, U.S. attorneys may or may not directly conduct negotiations, depending upon the situation. Many observers have evaluated the skills necessary to do this. ${ }^{120}$ Perhaps the most important of these is patience, a virtue not often extolled in our adversarial system: "The Chinese are excellent at brinkmanship, and their patience often seems endless." 121

\section{Alternative Dispute Resolution}

Most businesses are now aware that "[t]o avoid the unpredictable and sometimes corrupt Chinese court system, [foreign] investors might add a clause to their contracts which specifies that contractual disputes will be settled through arbitration." 122

Both arbitration and mediation are forms of alternative dispute resolution; both seek to resolve disputes outside of the traditional courtroom setting. They are distinguishable in that with arbitration, the parties agree to empower a third person to act as a judge and render a binding decision. A mediator has no such binding authority. Rather, the mediator's job is to help the parties reach an agreement between themselves.

U.S. attorneys might advocate for their client's position during Chinese

117. Id.

118. Id. at 405 .

119. Id.

120. See generally Jeffrey C. Y. Li, Comment, Strategic Negotiation in the Greater Chinese Economic Area: A New American Perspective, 59 ALB. L. Rev. 1035 (1996) (discussing the skills and strategies for negotiating in China).

121. Id. at 1059.

122. Ellen Reinstein, Finding a Happy Ending for Foreign Investors: The Enforcement of Arbitration Awards in the People's Republic of China, 16 IND. INT'L \& COMP. L. REV. 37, 37 (2005). 
arbitration proceedings, or they might serve as arbitrators themselves. Because arbitration is, by definition, not a court proceeding, it seems likely that U.S. attorneys could perform these functions even in China. Enforcing these judgments in China may, however, require resorting to Chinese courts.

Mediation involves an effort by disputing parties to sit down and, using the mediator as a go-between, attempt to reach a settlement acceptable to both sides. The parties have an opportunity to craft their own settlement instead of having a third party impose one upon them (as in arbitration or court).

"Interest in mediation is rocketing, in countries of all legal traditions. ... [T]he head of [the Centre for Effective Dispute Resolution] talks of a 'global revolution." "123 U.S. attorneys can serve as mediators, or they can represent clients as advocates in mediation. Because an arbitration award might find its way into Chinese courts anyway, mediation is appealing for U.S. businesses in China. If an American business can jointly arrive at a resolution with its Chinese counterpart - a resolution which the Chinese entity is voluntarily accepting - it is more likely that the U.S. firm will get what it desires out of the process. American attorneys who are certified mediators, or who have mediation or arbitration experience, can apply their skills in the Chinese context.

\section{Lobbying}

Many U.S. lawyers become lobbyists. "Classical economists did not anticipate a world in which developing nations like China and India could win in both skilled and unskilled labor, producing both cheap low-value items and cheap high-value items." ${ }^{24}$ Small businesses in the U.S. are being squeezed extra hard by competition: "small firms do not have the clout in Washington to obtain the benefits large firms get written into trade deals.... [And] once trade deals are signed, the government often has no plan to help entrepreneurs benefit." 125 An enterprising attorney might build a business around representing the policy needs of small businesses and entrepreneurs with respect to China.

A new frontier in lobbying is emerging - this time in China. The extent to which foreign firms might reasonably hope to influence China's business and

123. Knocking Heads Together, ECONOMIST, Feb. 1, 2007, at 62.

124. Joshua Kurlantzick, Broken Bridges: For Entrepreneurs, the Real Trade Barriers Lie Close to Home, ENTREPRENEUR, Jan. 2007, at 30, available at http://www.entrepreneur.com/article/printthis/171886.html.

125. Id. Kurlantzick writes,

I have encountered many U.S. entrepreneurs working overseas, but I've never found any who credited federal or state agencies for their success. Just the opposite. When I asked one . . . if he'd gotten assistance from the U.S. government, he just laughed in my face. And unless small companies start advocating for their exporting needs in Congress, they'll have to continue laughing - or crying.

Id. 
trade policies remains unclear. Once more, enterprising attorneys from the United States might find undiscovered opportunities by lobbying (formally or informally). This may be most tenable at the local level in China, where regional officials are in more frequent contact with foreign investors in their localities.

\section{Other Substantive Legal Functions}

American attorneys have a variety of other avenues they can pursue in the law with respect to China: international financing; political risk insurance; international payment methods; secured transactions; e-commerce; intellectual property; international antitrust; securities; U.S. taxation of international transactions; export controls, sanctions, and anti-boycott laws; government procurement; the legalization of documents for use abroad; creditors' rights and bankruptcy; foreign investment in the U.S.; immigration; international laborand-employment law; wills, trusts, estates, and related taxes; and family law (including transnational adoptions). ${ }^{126}$ Even those attorneys in small or sole practice ${ }^{127}$ should take notice, as many needs such as immigration and matters related to family law arise for individuals. Some well-established fields, including international environmental law, humanitarian law, admiralty law, and academia are also benefiting from China's rise. ${ }^{128}$

This amazing variety illustrates two harbingers for the future of the American legal profession. First, the business of law will be healthy with respect to China as a great deal of work presently exists and a great deal more will be created. Secondly, attorneys of all types can find something of interest in the law related to China.

\section{B. Legal Employment Options}

For American attorneys pursuing a legal career related to China, several employers stand out. These include law firms, consulting firms, businesses (inhouse counsel), a wide array of government agencies, and smaller operations (small firms and solo practice). Each of these is considered below.

\section{U.S. Law Firms: Both U.S. and China Offices}

Law firms are the most significant business organizations within the legal profession. In addition to competitive salaries, large firms command a variety of resources, including many of the most important intangible resources

126. See generally INTERNATIONAL LAWYER's DesKBooK (Lucinda A. Low, Patrick M. Norton \& Daniel M Drory eds., 2d ed. 2002) (providing detailed information regarding each of these areas of law).

127. See infra Part IV.B.5 (discussing small and sole firm China practices).

128. See generally CAREERS IN INTERNATIONALLAW, supra note 42 (providing information regarding these areas of international law). 
necessary to succeed in China: intellectual capital, broad networks within the legal and business communities of the United States and China, and information. While many American firms staff their offices in China primarily with Chinese lawyers, there is still plenty of room for American attorneys. On the whole, American law firms appear convinced that attorneys from the United States are among the best-trained and best-qualified to staff their ranks.

Those who are inspired by the thought of working overseas in a firm setting are in luck as "[c]ertain foreign offices recently began recruiting new U.S. law school graduates. Firms justify this practice by pointing to a foreign office's larger legal staff, which enables transactions to be staffed by more than one lawyer, thus leading to a greater capacity to train new lawyers." ${ }^{29}$ No concrete data currently exist, but one might expect this general trend to apply in China as readily as anyplace else.

Large U.S. law firms undoubtedly suffer some drawbacks, as any employer does. In all likelihood, the same lifestyle and intensity of work pervades international firms as much as purely domestic ones. From a business perspective, U.S. law firms going overseas sometimes fail to conduct Michael Porter's five forces analysis, a standard in academic business and strategic consulting circles. In particular, law firms often neglect to appreciate the full gauntlet of competition that awaits them overseas. ${ }^{130}$ Naturally, the greater the range of services a law firm or individual lawyer offers, the more competitors it will encounter. Law firms, like the business clients they represent, must make strategic choices about their operations in China. Poor strategic leadership can have disastrous results for a firm operating in the pressure of the Chinese environment. U.S. lawyers considering a career with an international law firm should do their homework first to ensure that the firm's management team is business-minded, and not merely law-minded.

Adding to the pressure on U.S. law firms are clients themselves. Supply chain technology is now routinely deployed by clients to ensure value: "In law

129. Carole Silver, Lawyers on Foreign Ground, in CAREERS IN INTERNATIONAL LAW, supra note 42 , at 1,9 .

130. "Competitors" are simply "companies that satisfy the same customer need." PHILIP KOTLER, A FRAMEWORK FOR MARKETING MANAGEMENT 127 (3d ed. 2007).

By vigorously invoking unauthorized practice of law statutes and the professional rules of conduct against assisting nonlawyers in the practice of law, state bar associations [in the United States] have managed to prevent a large-scale entry into the [United States] marketplace of corporate competitors such as financial advisors, banks, and insurance companies. Outside the United States, however, these competitors regularly joust with law firms for the legal business of large commercial organizations. The failure of U.S. law firms to appreciate this difference in the marketplace is one reason they have encountered serious financial problems in establishing and maintaining profitable branch offices in other countries. They have misunderstood the marketplace and misidentified their competition.

Mary C. Daly, The Cultural, Ethical, and Legal Challenges in Lawyering for a Global Organization: The Role of the General Counsel, 46 EMORY L.J. 1057, 1085-86 (1997) (emphasis added). 
firms and other contexts, supply-chain technology allows clients to carefully scrutinize what they are receiving for dollars spent, and thus what legal functions might be better or more economically performed in-house."131 One should be wary of an employer that cannot distinguish itself in the marketplace on the basis of quality, efficiency, and innovation.

\section{U.S. Consulting Firms: Both U.S. and China Offices}

Two forces have motivated consulting firms to bring attorneys into their ranks. First, most consulting firms, particularly those of the managerial and strategic variety, aspire to be full service providers for their clients. Since the law is so fundamental to business, the best consulting firms account for the law in the strategic consultations they perform. Two of the largest and most prestigious consulting firms, McKinsey \& Company and Boston Consulting Group, seek holders of advanced professional degrees, and both expressly seek applicants who hold JDs. ${ }^{132}$

Second, the skills valued by consulting firms overlap with legal skills. Watson Wyatt Worldwide is typical in that it seeks candidates who are selfmotivated, detail-oriented, possess strong computer prowess, and hold a "degree in a field that requires analytical thinking." 133 While JD students have been known to joke about attending law school because their math skills are unrefined, the opportunity to use math in law school and in practice exists for those who desire it, particularly in business-related classes and in transactional matters involving business clients. For lawyers with MBAs, the analytical dimension is enhanced even more. ${ }^{134}$

As the complexities of the Chinese environment continue to multiply, the demand for lawyers in consulting will grow as well. ${ }^{135}$

\section{Corporate In-House Counsel: Both U.S. and China Offices}

For some American corporations doing business in China, it may be economical to hire an in-house attorney with expertise in Chinese law and culture. An informal survey of the market suggests that most corporations in need of China expertise still outsource this function (i.e., hire a law firm). Still, the demand in corporate law departments for in-house personnel with expertise

131. Michael A. Hitt, Leonard Bierman, \& Jamie D. Collins, The Strategic Evolution of Large U.S. Law Firms, BUS. HoRizons, Jan.-Feb. 2007, at 27.

132. See McKinsey \& Co., Apply Now, http://www.mckinsey.com/careers/how_do_i_apply/apply_now.aspx (last visited Mar. 17, 2008). See also Boston Consulting Group, Join BCG, http://www.bcg.com/careers/ (last visited Mar. 17, 2008).

133. Watson Wyatt Worldwide, Skills http://www.watsonwyatt.com/careers/graduates/graduates_skills.asp (last visited Mar. 17, 2008).

134. Infra Part VI.B.1.

135. See infra Part V.B.2 for more on China-consulting and the U.S. attorney. 
in Chinese law is likely to climb. The same may eventually be true for Chinese firms seeking experts in U.S. law:

[t]he proactive model of lawyering springs from personal and professional traits seemingly unique to U.S. lawyers. It is characterized by a "can do" attitude that focuses on problemsolving and mixes business and legal counseling with little concern for the boundaries between them. It is closely related to another distinct phenomenon of U.S. lawyering known as "legal entrepreneurialism.",136

An in-house lawyer in China will face a variety of challenges. First, the in-house counsel must "educate the foreign law firms that serve as outside counsel ... with respect to her clients' expectations, thereby encouraging them to adopt a new, more expanded role."137 The in-house counsel "must also educate the organization's foreign employees . . . to accept the proactive counseling of U.S. lawyers."138 Both of these require cultural and communication skills which U.S. attorneys should possess anyway.

Ethical duties imposed upon American attorneys, including the attorneyclient privilege, may prove difficult to apply in the international context, ${ }^{139}$ because legal ethics codes differ or simply do not exist in other countries. ${ }^{140}$ U.S. lawyers serving a corporation in China must take care not to run afoul of ethical obligations while at the same time respecting the demands and cultural expectations of Chinese society.

\section{U.S. Government Agencies}

The U.S. government employs a large number of attorneys, many of whom may get the opportunity to do work related to China. International trade and customs laws are a principal source of China-related government work, ${ }^{141}$ though there are others. ${ }^{142}$ While government attorneys are not paid nearly what the private sector fetches, government employees are consistently ranked among the most satisfied with their jobs. Less stress, fewer hours, and competitive benefits attract many attorneys to government employment, and most view their jobs as compatible with family life. In addition, government attorneys may have the opportunity to assist companies going to China, ${ }^{143}$ and

136. Daly, supra note 130 , at 1068.

137. Id. at 1078.

138. Id. at 1080 .

139. See id. at 1099-108.

140. See id. at 1090-99.

141. See supra Part IV.A.4.

142. See Lewis, supra note 109, at 109-11 (listing opportunities in the U.S. government, most of which are related to international trade law).

143. See, e.g., U.S. Commercial Service, China, How We Help U.S. Companies, 
former government attorneys entering private practice may have a competitive edge based upon their knowledge and experience in government.

\section{Small Firm or Sole Practice}

Even small law firms and sole practitioners can enjoy a China-related practice. While this is a path less taken, ${ }^{144}$ career advice is available to American attorneys desiring to go this route. ${ }^{145}$ It is likely that the small firm or sole practitioner will focus on servicing individual clients, as opposed to corporate clients, in such areas as immigration and family law. The degree to which smaller firms and sole practitioners can compete effectively in China has not been quantified. However, it seems likely that with corporate clients hiring larger firms, and with larger firms focusing on their corporate clients, individuals will likely seek smaller, less expensive alternatives to the large firms for their legal needs in China.

\section{REGULATORY LIMITS UPON THE PRACTICE OF LAW IN CHINA}

\section{A Patchwork of Restrictions - Mainland China}

China is now a member of the WTO and, like other members, has agreed in principle to open most industries to foreign competition; however, there are several exceptions. One such exception applies to the practice of law. With respect to professional services, "China will permit foreign majority control except for the practice of Chinese law (an exception common among many WTO members)."146

The Working Party on China's Accession enumerated those functions that foreign law firms may perform in China:

(a) to provide clients with consultancy on the legislation of the country/region where the lawyers of the law firm are permitted to engage in lawyer's professional work, and on international conventions and practices; (b) to handle, when entrusted by clients or Chinese law firms, legal affairs of the country/region where the lawyers of the law firm are permitted to engage in lawyer's professional work; (c) to entrust, on behalf of foreign

http://www.buyusa.gov/china/en/howhelpus.html (last visited Mar. 17, 2008).

144. See, e.g. Law Offices of Aaron Schildhaus, Practice Areas, http://www.schildhaus.com/practice.html (last visited Mar. 17, 2008) (providing an impressive illustration of the sole practitioner in international law).

145. See generally, e.g., Jeffrey M. Aresty \& Ansrew S. Breines, Using the Internet to Run a Small-Firm International Business Law Practice, in CAREERS IN INTERNATIONAL LAW, supra note 42, at 23 (discussing the role of the Internet in international law).

146. Yadong Luo, How to ENTER China: Choices and Lessons 46 (2000) (emphasis added). 
clients, Chinese law firms to deal with the Chinese legal affairs; (d) to enter into contracts to maintain long-term entrustment relations with Chinese law firms for legal affairs; [and] (e) to provide information on the impact of the Chinese legal environment. ${ }^{147}$

This list of approved functions conspicuously lacks the authority to represent clients in Chinese courts (foreigners may not become members of the Chinese bar). Yet we have also noted that this glaring omission is not, in practice, as great a loss for foreign lawyers as one might expect. Native Chinese and foreigners alike distrust the Chinese court system, and most legal disputes in China are settled outside of the courts.

Still, the no-court restriction, together with a prohibition against foreign firms directly employing Chinese lawyers, ${ }^{148}$ has provoked some to complain to the government. ${ }^{149}$ Ironically, China's own regulations preventing foreign firms from employing Chinese attorneys are depressing the number of Chinese lawyers who are able to gain international training. This in turn artificially inflates the relative value of American attorneys in China, who do have international training and exposure. This favors U.S. attorneys in China because the number of domestic competitors is reduced. For now, the only effective tradeoff is the seldom-desired ability to appear before Chinese courts. Perhaps American attorneys should advocate for the retention of the current restrictions. After all, "the flood of foreign investment into China has given overseas law firms all the work they can handle."

\section{A Genuinely Liberalized System - Hong Kong}

When the British returned Hong Kong to Chinese authorities in 1997, Beijing guaranteed it would preserve many of the city's most-cherished features. Today, while Hong Kong is a part of China (it is a "special administrative region" or "SAR"), it retains a relatively unfettered capitalist economy, ${ }^{151}$ as well as its own legal system. Hong Kong serves as an example of what a truly capitalist China could look like.

147. Working Party on the Accession of China, Schedule of Specific Commitments on Services List of Articles II MFN Exemptions, WT/ACC/CHN/49?Add.2 (Oct. 1, 2001), available at $\mathrm{http}: / / \mathrm{www}$.uschina.org/public/documents/2005/05/specificcommitment.doc.

148. Bill Savadove, Barriers to Foreign Law Firms Decried, S. CHINA MoRnING Post, Dec. 25, 2006, at 6 . Of course, so long as U.S. law firms cannot directly employ Chinese lawyers to staff their Chinese offices, American lawyers must fill the void: a benefit for American lawyers wanting to establish a China-related career. See id.

149. Id.

150. Id.

151. Before China joined the WTO, Hong Kong was a member state on its own. See World Trade Organization, Member Information: Hong Kong, China and the WTO, http://www.wto.org/english/thewto_e/countries_e/hong_kong_china_e.htm (last visited Mar. 17, 2008). 
Several differences exist between mainland China and Hong Kong. Mainland China, as mentioned above, is a civil law country and does not allow foreigners to join its bar. In contrast, Hong Kong inherited a common law system from the British and does allow foreigners to become full members of its bar. Hong Kong, like Great Britain, recognizes two categories of lawyers. Solicitors are lawyers who are authorized to meet with clients and prepare legal documents, but who do not have the authority to appear in a court of law on the client's behalf unless specifically authorized. ${ }^{152}$ Barristers, in contrast, are lawyers who are fully empowered, so that they may appear in a court of law on behalf of a client. ${ }^{153}$ While the majority of lawyers in Hong Kong are solicitors, foreign lawyers may seek admission to the Hong Kong Bar as barristers. ${ }^{154}$ To do so, an American attorney must satisfy three major requirements: (1) he or she must be admitted to practice law in the United States, be in good standing, and have practiced law for three years prior to taking the Hong Kong Bar Exam; (2) he or she must take and pass the Hong Kong Bar Exam; and (3) he or she must spend a period of time (usually twelve months, but sometimes as few as three) practicing law under the direction of an experienced lawyer (this apprenticeship is referred to as one's "pupilage"). ${ }^{155}$

For U.S. attorneys who do not know Chinese, Hong Kong removes a substantial hurdle. ${ }^{156}$ The Hong Kong Bar Exam is in English, most legal documents are written in English; and most trials are conducted in English (although documents can be drafted in Chinese and a minority of trials are now conducted in Chinese).

Unfortunately, no formal review course currently exists for the Hong Kong Bar Exam. This means that American lawyers contemplating the exam must prepare for it entirely by themselves. A very helpful document provided by the Hong Kong Bar Association, however, guides foreign lawyers through the exam topics and makes extensive recommendations of English-language materials for preparation. ${ }^{157}$

152. BLACK's LAw DictionaRY 1427 (8th ed. 2004).

153. Id. at 160 .

154. See Legal Practitioners Ordinance, (1997) Cap. 159, 4, § 1(b), (H.K.), available at http://www.legislation.gov.hk/blis_ind.nsf/da97f6a8ed400207482564820006b580/1a4bfca29d9 2b04c48256cca002aeddb?OpenDocument; Hong Kong Bar Association, Admission and Registration Rules, http://www.hkba.org/admission-pupillage/general/index.html (last visited Mar. 18, 2008).

155. See Hong Kong Bar Association, Admission Under S.27(1) of the Legal Practitioners Ordinance, http://www.hkba.org/admission-pupillage/images/chart.pdf (last visited Mar. 18, 2008) (providing a useful flowchart/timeline on how to seek admission to the Hong Kong bar as a foreign lawyer).

156. While many contend that a mastery of Chinese is not necessary for working in mainland China, it is undoubtedly very helpful. See infra Part VI.B.2.

157. The document, entitled "Hong Kong Bar Association: Admission of Overseas Lawyers," is broken into four different PDF files on the Bar Association's website. See Hong Kong Bar Association, Information Package 2007, available at http://www.hkba.org/admissionpupillage/info-package2007.pdf; Hong Kong Bar Association, Examination Supplement, available at http://www.hkba.org/admission-pupillage/exam-supp2007.pdf (last visited Mar. 17, 
One might ask, in light of mainland China's rise, ${ }^{158}$ why an American lawyer would bother with Hong Kong. One expert suggests that Hong Kong facilitates, and will continue to facilitate, operations between mainland China and the west: "[T]he same compelling factors that led foreign investors to set up operations in the British Crown Colony of Hong Kong apply to the Special Administrative Region. Hong Kong has one foot in China and one foot in the west and facilitates dealings between the two." 159

This same expert persuasively argues that Hong Kong will remain a valuable base for corporate Chinese operations or law firms serving corporations. Hong Kong's legal system is preferable to mainland China's, because it is more transparent and is a common law system similar to that of the United States. Additionally, knowledge and information are more readily available in Hong Kong, human resources are favorable, and transportation links connect Hong Kong to the mainland. ${ }^{160}$ Furthermore, Hong Kong is a major global finance center, it enjoys its own remarkable foreign direct investment, and it has a more attractive tax system. ${ }^{161}$

Hong Kong's economy should continue its trailblazing ways. It is an especially appealing environment for entrepreneurs. One Hong Kong business leader has stated, "[w]hat's driving Hong Kong is a large number ... of small and midsize enterprises .... Hong Kong is producing a new breed of company."

\section{THE MECHANICS OF BUILDING A CHINA-RELATED BUSINESS CAREER}

The practice of law in the new China is now within reach of American attorneys, but some of our most exciting possibilities are the inviting overtures of the business world. This section first explores how American attorneys who continue to practice law can proactively extend their interests in the Chinese business environment. It then considers the most promising career options outside of legal practice.

\section{A. The Synergy of Law and Business: Equity for Services}

It may occur to the American lawyer practicing in China that as profitable

2008); Hong Kong Bar Association, Syllabus and Reading Lists for the Examination, available at http://www.hkba.org/admission-pupillage/Syllabus-and-ReadingList.pdf (last visited Mar. 17, 2008); Hong Kong Bar Association, Specimen Questions/Past Papers, available at http://www.hkba.org/admission-pupillage/specimen2007.pdf (last visited Mar. 17, 2008).

158. See supra Part II.

159. Sharon J. Mann, Hong Kong as China Headquarters, in CHINA AND Hong KONG IN LEGAL TRANSTTION: COMMERCIAL AND HUMANITARIAN Issues 151 (Joseph W. Dellapenna \& Patrick M. Norton eds., 2000).

160. See id. at 151-55.

161. See id. at 155-62.

162. Joan Magretta, Fast, Global, and Entrepreneurial: Supply China Management, Hong Kong Style - An Interview with Victor Fung, in HARVARD BUSINESS REVIEW ON MANAGING THE VALUE ChaIN 29, 58-59 (2000). 
as the law is, there are many high-growth business ventures that could prove still more lucrative. Yet for many of these attorneys, the law suits them well. As it turns out, it is possible to retain one's legal practice while simultaneously expanding one's interests in the Chinese business realm. Doing so requires finding the right clients and a willingness on the part of the attorney to embrace some higher-than-normal risks. In short, U.S. attorneys operating in China can accept part-ownership in a business entity in lieu of monetary payments in exchange for their legal services. In essence, such an arrangement makes the lawyer a venture capitalist, except that the lawyer provides legal services instead of cash to the client.

The Model Rules of Professional Responsibility explicitly endorse this type of arrangement, provided it is done in the form of a contingency fee. ${ }^{163}$ Equity-for-services is an appealing notion as, over time, an American attorney in China can build a private portfolio consisting of a variety of former clients. All of the benefits of small-business ownership - including monies from dividends or partnership payouts, capital gains from selling the stake, or proceeds from going public - would accrue to the attorney.

There are a number of considerable risks inherent in this arrangement, however. First, the lawyer must have enough cash that he can afford to provide legal services in exchange for something other than cash. This implies that a lawyer could not make a practice exclusively out of equity-for-services unless he has some other reliable source of income. Second, few closely held businesses will want to part with equity interests unless they must. This implies that the type of client an equity-for-services attorney will generally seek out are those desperate for legal help and short on cash. Third, the rate of failure among start-up companies is high in the brutally competitive business environment of China. An equity-for-services attorney could find his or her ownership interest in the business worthless if the company goes bankrupt. Lawyers embracing the equity-for-services model must therefore scrutinize the clients they agree to represent. The skills of a good venture capitalist are necessary. Fourth, the Model Rules require equity-for-services arrangements to take the form of a contingency fee if the equity interest is itself the cause of action or subject of litigation. ${ }^{164}$ This means that if the lawyer performs the legal services needed but has not fulfilled the contingency, he is not entitled to the equity interest contracted for.

A fifth risk inherent in equity-for-services arrangements is the fact that the lawyer will rarely possess a majority interest in the enterprise. Few small business owners would be willing to sign away their creation in exchange for legal services. ${ }^{165}$ Even if the lawyer could find someone willing to give them a

163. See Model Rules of Prof'L Conduct R. 1.5 (c), R. 1.5 cmt. 4, R. 1.8(i)(2), \& R. 1.8 cmt. 16 (2006).

164. See supra note 163 , at R. 1.8(i)(2).

165. On the other hand, entrepreneurs who are willing to give a controlling interest in the business to venture capitalists may be willing to do so for attorneys but only if the legal services 
controlling interest, he would then be responsible for ensuring the business's well being, lest his newly won interest become valueless. A lawyer desiring the time to continue practicing law would be ill advised to accept a majority interest unless he already has trusted and competent people to whom he could delegate the day-to-day operations of the business. Finally, the equity-forservices attorney assumes the same risk that can beset minority shareholders of closely held corporations in the United States: the majority owner may orient the business in a direction frustrating to the minority owner-attorney. For example, the minority owner-attorney may want the small corporation to declare dividends while the majority owner may want to reinvest the corporation's revenues back into the business. This risk, more so than the others above, can be abated by the initial attorney-client contract. ${ }^{166}$

Additionally, U.S. attorneys must consider the restrictions that U.S. federal law places on the manner in which American professionals achieve results overseas. The principal concern in this regard is the Foreign Corrupt Practices Act, which forbids bribes to foreign officials and specifies mandatory recordkeeping practices for many publicly traded interests. ${ }^{167}$ Practice in China, then, can present difficult ethical situations. American attorneys must be most vigilant. ${ }^{168}$

With all of the risks inherent to the equity-for-services arrangement, it is no surprise that few attorneys appear to pursue this route. Nevertheless, for the ambitious entrepreneurial lawyer who wants both a continuing legal practice and a portfolio that extends beyond the law, equity-for-services offers an option to help achieve this goal.

\section{B. From Law to Business - The Majesty of the Magic Confluence}

Some of the most exciting opportunities for U.S. attorneys in China can be found outside of the practice of law altogether. These opportunities share the common requirement of innovation. Two insightful consultants define innovation as the product of creativity and risk taking. This has been expressed as an equation: "Innovation $=$ Creativity $x$ Risk Taking." 169 International

provided are as crucial to the survival and/or expansion of the business as cash would be in the ordinary case of venture capital.

166. For example, the lawyer could agree to become a minority owner with respect to dividends but have a disproportionately large voice in managerial decisions. It does not appear that any Chinese laws or regulations forbid such an arrangement, but this possibility assumes that none exists.

167. See generally StUART H. Deming, The Foreign CoRruPt PRACTICE ACT AND THE NeW INTERNATIONAL NoRMS (2005) (discussing the Foreign Comupt Practices Act). See also id. at 10 (highlighting the basic elements of the anti-bribery provisions).

168. For a supremely eloquent and practical synopsis of the ethical issues arising for transnational lawyers licensed in the United States see Ronald A. Brand, Uni-State Lawyers and Multinational Practice: Dealing with International, Transnational, and Foreign Law, 34 VAND. J. TRANSNAT'L L. 1135 (2001).

169. JaCQUELINE ByRd \& PaUl LoCKWOOD BRown, The INNOVATION EQUation 22-23 (2003). 
lawyers must be creative and not overly risk-averse. As such, within ethical bounds, a legal practice related to China can serve as a staging ground. To be effective, American attorneys in China must be creative in crafting legal arguments $^{170}$ and in finding solutions to complex problems.

More specifically, creativity is driven by four factors: the ability to operate in an ambiguous situation, independence, inter-directedness, and uniqueness. Somewhat analogously, risk-taking is driven by three factors: authenticity, resiliency, and self-acceptance. ${ }^{171}$ As any experienced lawyer will attest, a successful legal practice depends on developing these skills. Those lawyers who do so best, and who embrace risk, are well positioned to excel in the business world. American attorneys can enter business as innovators by virtue of their legal experience.

Lawyers tend to under-appreciate the transferability of legal skills. As one authority puts it,

[o]ur work as lawyers helps us develop and perfect a wide variety of skills used and valued in other environments: for example, negotiation and persuasion; gathering, organizing and analyzing data; simplifying complex concepts; oral and written communication [.] . . . Many of us, however, get so used to thinking in technical terms - taking depositions, writing briefs, filing motions, drafting contracts - that we are unable to see the relationship between our legal experience and the demands of other fields. ${ }^{172}$

Lawyers determined to enter the Chinese business environment must place a premium upon innovation and the development of these transferable skills.

\section{Corporate Leadership}

"The diversity of corporate positions currently held by people with legal training is evidence of the vast range of opportunity ...." ${ }^{\prime 17}$ Lawyers rise in corporate ranks in many areas such as tax, finance, government relations, risk management, regulatory compliance, contract administration, marketing, and intellectual property. ${ }^{174}$ One law school advises that "[m]any options are

170. This is not a metaphor advocating specious argumentation. Rather, the law, by its very nature, requires lawyers to consider all dimensions of a given question. Approaching a question in a new way need not be intellectually dishonest; innovative legal arguments are made in good faith every day in matters throughout the United States.

171. BYRD \& BROWN, supra note 169, at 48-68.

172. Deborah Arron, Nontraditional Careers for Lawyers, in ChANGING JoBs: A HANDBOOK FOR LAWYERS IN THE NEW MILLENNIUM 302 (1999).

173. Gary A. Munneke \& William D. Henslee, Nonlegal Careers for Lawyers 54 (4th ed. 2003).

174. Id. at 54-79. 
available [for law school graduates] in the world of business" including "[m]anagement positions and entrepreneurial ventures." However, "[n]ontraditional careers are not easy to get. They require patience and persistence and an all-out effort. Contacts are important ...." Still, "[m]any of the CEO's of Fortune 500 companies are attorneys." 175

An American corporation is more likely to appoint a manager in China after the individual has proven herself capable in the United States. Consequently, American attorneys aspiring to a managerial position with a U.S. corporation in China should first seek experience in the domestic corporate ranks. This can be accomplished by working for the in-house counsel's office or by entering the ranks of management.

Although it can easily be assumed that U.S. corporations will turn to native Chinese managers when seeking to fill managerial positions in their Chinese offices, "[b]urgeoning economies in Asia have increased the demand for high-quality global managers with MBAs."176 Numerous commentators from both the United States and China have observed that on the whole, Chinese management does not approach the level of global sophistication that many American companies have achieved. ${ }^{177}$ To date, Chinese business schools have been completely unable to remedy the competitive gap. ${ }^{178}$

\section{Consulting}

Fundamentally, consultants and attorneys provide the same basic services: they resolve their clients' problems or help clients avoid problems. Consulting, then, is a sister occupation to the law, ${ }^{179}$ one that is potentially as challenging and exciting. Lawyers, most of whom have experience with the analytical rigors of resolving legal problems, will find the transition into consulting especially natural. In discussing Toyota's efforts to manage its supply chain, two academics note that "because participants at all layers speak the same language and follow the same principles, understanding is achieved with relative ease."180 This is also true of business law attorneys-turnedconsultants. Speaking the language of one's clients is an immense asset: it makes possible the communication necessary to solve complex problems in the real world. Few occupations prepare one to communicate so well as the law.

175. Indiana Law, Legal Career Options: Corporate Practice, http://www.law.indiana.edu/careers/guides/career_options_corporate.shtml (last visited Mar. 17, 2008).

176. Kerry Miller, B-School is Hip Again, Bus.WK. ONLINE, Aug. 7, 2006 (citation omitted). See also infra Part VI.B.1 (discussing the advantages of obtaining an MBA).

177. See, e.g., China's People Problem, Economist, Apr. 16, 2005, at 54.

178. See Dexter Roberts, China MBAs: Most Likely to Fall Short, Bus.WK., Dec. 4, 2006, at 106.

179. For more on consulting see supra Part IV.B.2.

180. Toshihiro Nishiguchi \& Alexandre Beaudet, Fractal Design: Self-Organizing Links in Supply Chain Management, in KNOWLEdGE CREATION: A SOURCE OF VALUE 199, 204 (Georg von Krogh, Ikujiro Nonaka, \& Toshihro Nishiguchi eds., 2000). 
Of course, communication is not the only qualification that attorneys bring to consulting. The knowledge and experience one garners through the practice of law translates directly into the consultant's role as a student of the client's problems and an engineer of the client's solutions.

Through [their] process of mutual learning, firms come to share a set of common "codes" and understandings . . . . Firms share result knowledge: that is, in the form of a solution to a given problem, which among other things helps firms identify which practices are effective .... They also share dense, contextual, and tacit process knowledge, enabling participants retrospectively to decode result information into directly applicable knowledge. In other words, firms share not only "information" but also "know-how" ... and often "knowwhy." 181

Of course, the facts of a client's case are crucial, and the emphasis placed upon case facts in law school reflects this. Every business problem an attorney confronts is like a real-world MBA case study. The insights attorneys gain into business clients and the legal process are invaluable in the world of consulting.

Attorneys are trained to look for creative solutions to their clients' problems; this can be further reinforced with an MBA. ${ }^{182}$ Legal experience involving the representation of business clients is directly transferable to the world of consulting. In particular, U.S. attomeys with legal (or other) experience in China are especially well positioned to move into China-related consulting.

One of the most redeeming features of consulting is that it can be undertaken anyplace in the world. An attorney-turned-consultant can advise clients on China-related matters while residing in the United States. One could also live and consult in China. Salaries at the largest consulting firms are highly competitive, many consulting positions involve travel, and the attorney can continue to be a real-world problem-solver.

\section{Venture Capitalism}

Venture capital is simply "[m]oney used to purchase [an] equity-based interest in a new or existing company." 183 By investing in high-risk start-up companies that need cash to grow, the venture capitalist hopes that the value of the company will appreciate quickly and substantially so that he can sell his interest for far more than his original investment. Typically, venture capitalists

181. Id. at 202-03.

182. See infra Part VI.B.1.

183. Venture Capital Glossary, Venture Capital, http://www.vcaonline.com/resources/glossary/index.asp (last visited Mar. 18, 2008). 
("VCs") contribute their money to funds, which are in turn managed by other VCs. Since entrepreneurs are normally the type of people who both need capital for their businesses and cannot get other sources of funding, ${ }^{184}$ venture capital is closely intertwined with entrepreneurship. "In truth, venture capital and private equity firms are pools of capital ... . Far from being simply passive financiers, venture capitalists foster growth in companies through their involvement in the management, strategic marketing and planning of their investee companies. They are entrepreneurs first and financiers second."185 Individual VCs, known as "angel investors," may also make investments in new companies, but this is a less common source of entrepreneurial capital than are the VC funds. ${ }^{186}$

In Part V.A we considered another form of venture capitalism available to U.S. attorneys in China in which the attorney comes to own part of the client company by providing legal services. In contrast, traditional VCs provide cash. ${ }^{187}$ As cash is the most fundamental asset to business, it is often the one most in demand.

VCs have been attracted to China in record numbers. ${ }^{188}$ Some enterprising law firms have already attached VC services to their legal operations: "[s]ome lawyers are taking a cue from their venture-capital clients - by investing in start-up companies that come to them for legal advice .... Some law firms are even reinventing themselves as venture capitalists and launching their own funds." ${ }^{189}$ Lawyers can compete:

law firms with their own venture funds have a bit of an edge because they "are perceived by entrepreneurs as being more entrepreneurial". . . . And attorneys see investment opportunities daily. When deciding to take on a client, law firms perform much of the same due diligence . . . before investing, so law firms have a bit of expertise in assessing whether a business plan is viable. ${ }^{190}$

184. Entrepreneurs often turn to VCs when banks and other established loan organizations deem the new business too risky.

185. National Venture Capital Association, What Is a Venture Capitalist?, http://www.nvca.org/def.html (last visited Mar. 17, 2008).

186. Id.

187. While VCs will undoubtedly provide highly valuable guidance to the companies in which they invest, their most important contribution is often cash.

188. Christopher M. Vaughn, Note, Venture Capital in China: Developing a Regulatory Framework, 16 COLUM. J. ASIAN L. 227, 228-30 (2002). For an illuminating discussion of the regulatory framework governing VCs in China, see id. at 243-47.

189. Raymond Hennessey, Deals \& Deal Makers: Lawyers Set Up Funds to Back Start-Up Clients, WALLST. J., July 13, 2000, at C22. Of course, American attorneys must be careful not to violate any ethics rules while acting as VCs. Id.

190. Id. 
The individual benefits of doing so can be substantial. ${ }^{191}$

The recently formed China Venture Capital Association has been increasingly active since its inception. ${ }^{192}$ As with other areas of business, VCs should also ensure a healthy working relationship with the entrepreneurs in whose companies they invest. ${ }^{193}$

\section{Entrepreneurship}

The innovative, savvy American lawyer seeking out entrepreneurial opportunities in China will find himself operating in a country that is undergoing changes of truly historic proportions. It is the world's greatest business frontier, the magic confluence - a climate in which all of the elements of a successful enterprise have come together in a place and a time unmatched by any other era. Today's American lawyer who follows his entrepreneurial spirit to China can become an alchemist writ large.

This assertion is not meant to suggest that U.S. attorneys will have it any easier or will necessarily succeed at a higher rate than other entrepreneurs. It is only to illustrate the uniqueness of the entrepreneurial opportunities of modern China, ${ }^{194}$ and that American attorneys are as well situated as anyone, Chinese or otherwise, to build a truly great business there. "A surprisingly large number of lawyers are entrepreneurs.", 195

A legal background undeniably adds skills and experiences to the wouldbe entrepreneur's repertoire, skills that few other professions can replicate as well. Running a commercial business is analogous to serving as a partner in a large law firm. ${ }^{196}$ There is evidence that an increasing number of Chinese lawyers are starting businesses there, particularly those who study law overseas. ${ }^{197}$ American attorneys, especially those with legal or other business experience in China, should not feel shy about following suit. Entrepreneurs should understand the law, ${ }^{198}$ and lawyers should internalize business.

191. Id.

192. See generally China Venture Capital Association, http://www.cvca.com.hk/index.asp (last visited Mar. 17, 2008).

193. See Manuel A. Utset, Reciprocal Faimess, Strategic Behavior \& Venture Survival: A Theory of Venture Capital-Financed Firms, 2002 WIS. L. REV. 45 (2002).

194. Of course, there are skeptics. See, e.g., Yasheng Huang, China is No Haven for Entrepreneurs, FIN. TIMES (U.S. ed.), Feb. 2, 2007 at 1 . The consensus, however, is generally one of optimism.

195. MUNNEKE \& HENSLEE, supra note 173, at 111.

196. Id. at 50-51.

197. "[I]n recent years a number of people who went abroad for law study ... have come back to start businesses in China. Their good command of both Chinese and Westem laws, coupled with the rich experience they have gained with international business, means that the highest level of law service in China is in line with the international level." Jiachun, et al., supra note 116, at 406 .

198. "An understanding of the law is especially important to entrepreneurs because the law touches every aspect of a new venture .... Students who acquire these tools ... will be better equipped to achieve success in entrepreneurial ventures." George J. Siedel, Six Forces and the 
As we will see below, ${ }^{199}$ relationships are of paramount importance to succeeding in China. Perhaps nowhere are relationships more important than in entrepreneurship. Anyone thinking about starting their own business in China must have a large network of people to draw upon, from potential business partners and legal counsel to potential employees and financial backers. ${ }^{200}$

Attempting to start one's own business is fraught with risks and challenges. Naturally, starting a business outside of the United States is even more daunting. The Chinese market is an extraordinarily competitive and complex place in which to operate. Yet American attorneys have the skills and potential to lead the world's next great wave of creation. In doing so, they can benefit not only themselves and the United States, but also further the development of the rule of law in China as well as friendship and understanding between the two countries. The more that Americans are involved in building China's economy, the more wealth will be created for the United States. The closer the ties between the United States and China, the more secure and stable each is likely to be. The magic confluence is calling upon American attorneys. Whether we answer or not is entirely up to us.

\section{LAYING THE GROUNDWORK FOR THE CHINA-FOCUSED CAREER}

\section{A. General Lessons}

A few general observations will substantiate the specific recommendations made below. First, it is clear that most of the opportunities awaiting U.S. attorneys in China are related to business (serving business clients or working in a business capacity). Increasingly, however, individuals require attorneys who specialize in matters related to China. ${ }^{201}$ Second, work experience in the American legal environment seems to be a universally useful prerequisite to making a career in China. Before leaving for China, the U.S. lawyer should seek at least a year of experience in the United States. Working

Legal Environment of Business: The Relative Value of Business Law Among Business School Core Courses, 37 AM. Bus. L.J. 717, 736-37 (2000).

199. See infra Part VI.B.9.

200. "VCs look for three things - people, people and people. VCs are as interested in the person bringing in the business as they are in the business itself." Drew Senyei, What Venture Capitalists Look For in Business Proposals, SAN DIEGo Bus. J., No. 4, Vol. 22, Jan. 22, 2001, at 29.

201. The most promising practice areas geared toward individual clients are those in which regulations are creating artificially high levels of complexity. International adoptions are a fine example. China will implement greater restrictions upon the adoption process, "barring people who are single, obese, older than 50 or who fail to meet certain benchmarks in financial, physical or psychological health from adopting Chinese children, according to adoption agencies in the United States." Pam Belluck \& Jim Yardley, China Tightens Adoption Rules for Foreigners, N.Y. TIMES, Dec. 20, 2006, available at http://query.nytimes.com/gst/fullpage.html?sec=health\&res=9400EFDC1031F933A15751C1A9 609C8B63. The more difficult the law makes it for individuals to accomplish their goals, the more they need attorneys. 
in a firm, in a judicial clerkship, or in any other analytical capacity, will better prepare the American attorney to succeed in China. Finally, people skills are as important to succeeding in China as are technical skills and knowledge. In whatever pre-China work the U.S. attorney does, his or her work should emphasize communication.

B. Specific Items $s^{202}$

\section{Obtain an MBA, Preferably from an American School}

The marketplace reflects the value of an MBA, a notion MBA graduates affirm. ${ }^{203}$ This holds true for people pursuing international careers as well. ${ }^{204}$ An MBA enables the attorney to better understand what issues to look for in the problems confronting their clients or in their own businesses. An MBA better equips attorneys with the technical knowledge to analyze and solve business problems. Most MBA graduates also develop a broader network of contacts. Of course, any coursework focused on China or international strategy is especially useful to pursuing a career in China.

Perhaps the greatest benefit of obtaining an MBA is learning the language of business and developing the vocabulary to communicate with individuals engaged in business. "[G]ood emerging business lawyers need to be able to talk to entrepreneurs in their own language."205 Knowing how to express one's ideas so that they are intelligible to the listener is crucial in the complex world of business, and understanding how to listen to a client is equally important.

202. Several U.S.-licensed attorneys practicing in China provided me their valuable insights with respect to the most important skills for American attorneys to possess in planning a China career. I would like to acknowledge and thank each of them individually (all are partners in their respective firms' Beijing offices, with offices other than Beijing also noted): Hon. Charlene Barshefsky (Wilmer Hale, Washington, D.C.); Joseph Cha (Heller Erhman, Shanghai); Dr. Lucas Chang (Morgan Lewis, Palo Alto, Califonia); Kalley Chen (King \& Wood); Gary Chodorow (Law Offices of Frederick W. Hong); Jon Christianson (Skadden, Hong Kong); Eliot Cutler (Akin Gump Strauss, Washington, D.C.); Paul Deemer (Vinson \& Elkins, Shanghai); Stephen Harder (Clifford Chance, Shanghai); Richard Lawrence (Holland \& Knight); David Livdahl (Paul Hastings); Manual Maisog (Hunton \& Williams); Matthew McConkey (Mayer Brown JSM); Michael Moser (O'Melveny \& Myers, Hong Kong); Steve Payne (White \& Case); Steven Robinson (Hogan \& Hartson, Shanghai, Hong Kong, Washington, D.C.); Anthony Root (Milbank Tweed, Hong Kong); Lester Ross (Wilmer Hale); Ben Tai (Jones Day); and Xiaohua (Sarah) Zhao (Akin Gump Strauss, Washington, D.C.).

203. See Graduate Management Admission Council, What Graduating MBAs Say, http://www.mba.com/mba/AssessCareersAndTheMBA/TheValueoftheMBA/TheMBAInTheMar ketplace/WhatGraduatingMBAsSay.htm (last visited Mar. 17, 2008).

204. See generally The B-School Net, The MBA - A Passport to an International Career, available at

http://www.b-school-net.de/MBA_news/archive_2004/topmba_04032004.htm (last visited Mar. 17, 2008).

205. Cliff Collins, The Engine of Growth: Lawyers Take a Lead in Helping Emerging Businesses to Grow, 59 OR. ST. B. BuLL. 9, 12 (1998). 
An MBA better enables the lawyer to do both.

American attorneys looking to work in China will be glad to have an MBA. China and its business environment are quite complex. The skills developed in a competitive MBA program compliment both the JD and legal experience nicely, affording the attorney a more comprehensive view of the world and a greater analytical skill set.

\section{Develop a Working Knowledge of the Chinese Language}

To better hone U.S. attorneys' competitiveness in a global economy, law schools should develop foreign language curriculums. One academic has argued that monolinguism leads to limitations on the imagination. ${ }^{206}$ The communicative advantages are equally compelling: "[t]he knowledge of one or more foreign languages is incredibly useful and often essential in some types of transnational law practice, particularly when a lawyer must spend substantial amounts of time in a foreign society. ${ }^{, 207}$ In China, where relatively few people speak English, the American attorney fluent in Chinese will likely find himself at a great advantage.

These realities are reflected in the hiring practices of today's international law firms.

The number of attorneys working in the foreign offices of law firms jumped last year by 23 percent, according to the National Law Journal, making U.S.-trained lawyers with foreign-language skills particularly sought-after applicants. The standard French or German will still come in handy, but aspiring lawyers may do even better to study Mandarin . . . . "A lot of European lawyers speak English fluently, but the Asian languages are a specialty much in demand."208

Learning a foreign language is no small undertaking, but every moment spent learning Chinese is a worthwhile investment for a practitioner interested in working in China. Determining which of the seven major dialects one should learn depends upon where or with whom one anticipates working. If this is uncertain, learning Mandarin is the most rational choice: it is the official language of China, and the one most widely spoken. ${ }^{209}$

206. Vivian Grosswald Curran, The Role of Foreign Languages in Educating Lawyers for Transnational Challenges, 23 PENN ST. INT'L L. REv. 779, 779-80 (2005).

207. Goebel, supra note 94 , at 451.

208. Nisha Ramachandran, Hiring Is Again in Vogue, U.S. NEWS \& WORLD REP. 1, available at http://www.usnews.com/usnews/edu/grad/articles/brief/gblawcareers_brief.php (emphasis added).

209. See Languages of China, Chinese Language Group Members, http://www.chinalanguage.com/content/index.php?c $=$ book\&id=179 (last visited Mar. 18, 2008). 


\section{Study the Complimentary Disciplines}

Liberal arts degrees are often maligned, but many of them are directly applicable to the U.S. attorney working in China or with Chinese parties. History, political science, sociology, psychology, and economics are especially useful to grounding one's understanding of the Chinese macro-picture. "In view of . . . the need for American transnational lawyers to assist clients in bridging the cultural gap, it is definitely desirable for an American law student to have some specialized education to help develop the particular skills necessary for such a practice."210

\section{While in Law School, Emphasize International Courses}

For the student interested in pursuing a career focused on China, or any other country, law school is an opportunity for the aspiring lawyer to learn all she can about the nature of transnational law. ${ }^{211}$ Any courses or studies abroad dedicated exclusively to China should be taken (regrettably, these remain limited), as should any courses pertaining to the fields one might practice in relation to China, such as trade.

\section{Obtain an LL.M. in Chinese Law, Preferably from a Chinese Law School}

The LL.M. degree, or "Master of Laws,""12 offers attorneys the option of earning an educational specialization. For American attorneys serious about a career focused on China, an LL.M. degree in Chinese law is a powerful tool. The curriculum of an LL.M. is likely to consist of a broad overview of key areas in Chinese law. Most LL.M. programs require either one or two years of full-time study.

The insights gained through an LL.M., as well as people met through such a program, directly translate into competitive capabilities for the U.S. lawyer in China. Writes one expert:

[an important] development on the educational front is the ubiquity of the LL.M. degree, not only for foreign lawyers studying in the United States, but also for U.S. lawyers studying overseas .... I can attest that there is really no substitute for these popular LL.M. programs. They provide a uniquely accessible opportunity to better the cross-cultural understandings so critical for a successful international legal

210. Goebel, supra note 94 , at $454-55$.

211. See id. at 455.

212. The degree is so named because law is an undergraduate degree in most countries, and was in the United States until the later half of the twentieth century. Consequently, even American attorneys who earn the Doctor of Jurisprudence take an LL.M. degree after the J.D. 
practice. $^{213}$

Clearly, China is the best place to study. ${ }^{214}$ Many of China's leading law schools, including Peking University, Tsinghua University, and Hong Kong University, offer LL.M. degrees in Chinese Law. All of these programs are geared toward western lawyers, as English is the language of instruction in all three. $^{215}$

\section{Seek Admission in Hong Kong}

Part IV.C. 2 revealed that Hong Kong occupies a unique position. Unlike in mainland China, American attorneys can take the Hong Kong Bar Exam and become fully licensed to practice law there. Particularly if one's law firm or entrepreneurial interests lie in Hong Kong, the U.S. lawyer should strongly consider gaining experience there and perhaps even taking the Hong Kong Bar Exam.

\section{Get Work Experience in China}

This seems like an obvious recommendation: "[t]rust is essential in a service economy where all a firm has is its reputation for dependability and good service."216 Working in China, regardless of the nature of the work, should be viewed as an opportunity to gain trust and lay the necessary groundwork for long-term success.

A Western lawyer should develop his own guanxi, building close friendships and gaining the trust of his Chinese counterparts through reliability, constant contact and a show of great interest in Chinese culture and way of life . . . The key to the Chinese legal market is not to try too much too soon and to remain patient at all times. Time spent in

213. Mark W. Janis, Perspectives of an Academic International Lawyer, in CAREERS IN INTERNATIONAL LAW, supra note 42, at 169, 173. See also Silver, supra note 1, at 933.

214. See Goebel, supra note 94 , at 456.

215. See Peking University, The Master of Laws (LL.M.) Program in Chinese Law, http://www.law.pku.edu.cn/llmp/En_001.asp (last visited Mar. 17, 2008); Tsinghua University, Master of Law (LL.M.) Program in Chinese Law: An Overview, http://www.tsinghua.edu.cn/docsn/fxy/english/llmPrgm.htm (last visited Mar. 17, 2008); and Hong Kong University, Master of Laws in Chinese Law, http://www.hku.hk/law/programmes/pp_llm_chinese.html (last visited Mar. 17, 2008).

216. Linda K. Trevino \& Katherine A. Nelson, Managing Business Ethics 49 (2007). Although the authors make this point to encourage ethical behavior, the notion is also applicable to why U.S. interests and individual attomeys must establish a physical presence in China - to build trust and credibility. 
reconnaissance and relationship building is never wasted. ${ }^{217}$

One law student who spent a summer as a legal assistant in a prominent Beijing law firm commented, "[the internship] looked amazing on my resume . ... As the world gets more interconnected, the opportunity for business has increased beyond (U.S.) borders .... It's an untapped market. I just wanted to get in on the ground of promoting business in China."218

American lawyers working in China should seek out the opportunity to befriend government officials, ${ }^{219}$ especially those local officials too often overlooked by Americans in China. Of course, all activities should conform to the Foreign Corrupt Practices Act and Rules of Professional Conduct. Healthy personal relationships can be formed over time, however, only if the American attorney is physically located in China.

\section{If You're Already Working ...}

For attorneys already in the workplace and who have not previously been involved with China in any way, the transition to a career focused on China is more challenging primarily because of the time investment that is required for such a transition. Those who are already working must be disciplined in identifying the investments of time and making priorities that will most likely help them in their career change. ${ }^{220}$

\section{Establish Credibility by Establishing Relationships}

Lawyers should enjoy solid relationships with their clients. ${ }^{221}$ In order to provide optimal assistance to clients and to succeed in non-traditional careers, the American lawyer must also establish relationships with people in China. "A single lawyer will often take on a large percentage of the work in China and can make all the difference whether a firm gets hired or not. 'In China today, you still hire the lawyer and not the firm,' says William Chua of Sullivan \& Cromwell.,"222

One expert advises,

[f]orget the organization charts ... As anyone with a

217. Edward Holroyd Pearce, Careers: Orienteering in the Chinese Legal Market, THE LAWYER, Oct. 16, 2006, at 49.

218. Maria Kantzavelos, Foreign Experiences Orient Law Students to a Globalizing Profession, ChICAgo LAWYER, May 1, 2006, at 12.

219. See Lieberthal \& Lieberthal, supra note 45 , at 15.

220. See generally Nancy D. Israel, Changes in Direction in a Legal Career, in CAREERS IN INTERNATIONAL LAW, supra note 42, at 93.

221. See Juncadella, supra note 68 , at 1.

222. James Rice, How to Choose the Best Local Lawyers for Equity Work, 24 INT'LFIN. L. REv. 1 (2005). 
modicum of experience in the PRC can tell you, the key to getting anything accomplished in China lies not in the formal order, but rather in who[m] you know, and in how that person views his or her obligations to you .... If you have guanxi, there is little you can't get accomplished, even if it is technically - or sometimes even brazenly - against the rules. If you don't have guanxi, on the other hand, the opposite might be true. Your life is likely to be a series of long lines and tightly closed doors, and a maze of administrative and bureaucratic hassles. ${ }^{23}$

The first order of business when arriving in China is to establish guanxi. ${ }^{224}$ Relationships can result in more than small personal favors; multimillion dollar deals, and even entire businesses, are made and broken based upon guanxi. ${ }^{225}$ The American attorney must bear in mind that there is a difference, even in China, between "networking" and creating bona fide relationships. ${ }^{226}$

Americans should not attempt to delegate the task of building guanxi to Chinese partners. "It is only the naïve and uninitiated who leave all the guanxibuilding to their Chinese partners. Good relationships with [decision-makers] charged with oversight of foreigners and their affairs are as good as gold in China." ${ }^{227}$ This, again, requires a physical presence in China to accomplish. "Guanxi is well within the grasp of foreigners who wish to cultivate it. Often all it takes is an overture ... [and] [f]oreigners who live and work in China may become integrated into relationship networks ...."228

American lawyers interested in China can make themselves all the more valuable by establishing their own guanxi apart from their company's. Relationships in China require diligence, however. Guanxi is, after all, "a renewable resource and can be reestablished even after much time has passed. But it may also be an exhaustible resource if the ledger between two people does not remain in approximate balance." ${ }^{, 229}$ For attorneys contemplating the leap into consulting or entrepreneurship, relationships can literally make the impossible possible. "The expression Duo yige guanxi, duo yitiao lu - 'One more connection offers one more road to take' - really says it all.",230

223. Scott D. Seligman, Chinese Business Etiquette 180-81 (1999).

224. Id. at 183 .

225. Id. at 181 .

226. See id. at $183-84$.

227. Id. at 188 .

228. Id. at 195 .

229. Id.

230. Id. at 182 . 


\section{Assume a Productive Mindset}

For American attorneys who incorporate China into their practice, patience and determination are the paramount virtues. Bearing this in mind will help attorneys to persevere. Experience shows that Americans can create longlasting business relationships in China. The potential language barrier, cultural gap, relative inexperience of many Chinese in dealing with westerners, and corruption are all barriers to effective guanxi-building. Yet these barriers can and must be overcome to maximize one's chances for success.

The American lawyer who conforms to Chinese mores, rather than expects the Chinese to conform to his, will find his Chinese acquaintances considerably more cooperative, and will discover that his business efforts are far more effective. While this appears to be a simple choice, it is sometimes difficult to keep the proper perspective while immersed in a foreign culture. The American attorney must always remember that his own attitude is the single most important factor in determining success or failure.

\section{CONCLUSION}

As the twenty-first century progresses, the United States and China will likely be the two most powerful and affluent nations in the world. American attorneys have great potential to not only advance their own prosperity but also help promote friendship between the two nations. Americans can help mold the rule of law in China while learning a great deal from the Chinese, and while expanding their business interests around the world. The American lawyer plays a unique and fundamental role in the global value chain, and if we approach that role correctly, U.S. attorneys can compete in China.

For the individual American attorney contemplating a China-related career, there are an immense number of practice areas within the law, and a correspondingly large number of potential employers. For those who may not always want to practice law, U.S. lawyers are competitively positioned to succeed in China as corporate leaders, consultants, venture capitalists, and entrepreneurs.

The magic confluence beckons us. If American attorneys are wise, we will not hesitate to respond. 
